
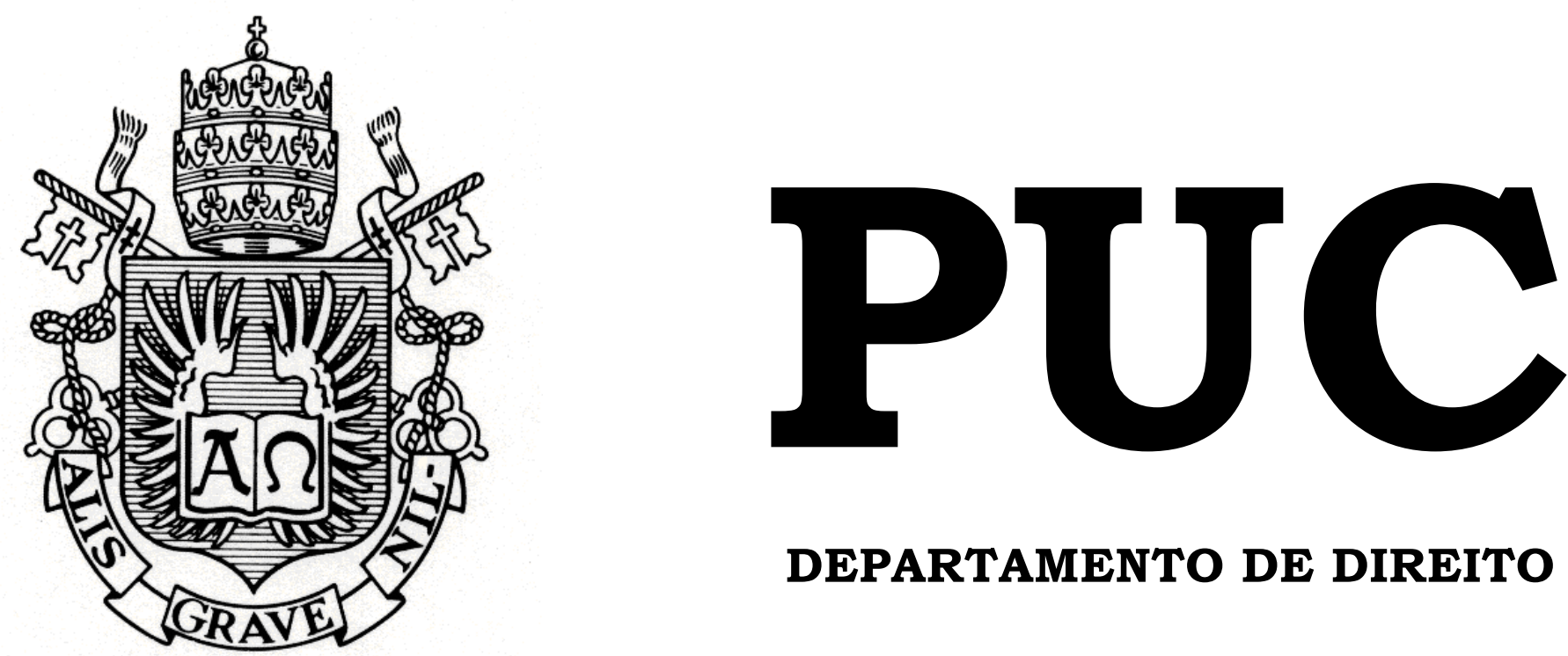

DEPARTAMENTO DE DIREITO

O JUIZ DE GARANTIAS E O PROJETO DE LEI No 8045/2010: A FUNÇÃO JURISDICIONAL NA INVESTIGAÇÃO PRELIMINAR À LUZ DA CONSTITUIÇÃO FEDERAL

por

PEDRO BRUZZI RIBEIRO CARDOSO

ORIENTADOR: SERGIO CHASTINET DUARTE GUIMARÃES 2019.1

PONTIFÍCIA UNIVERSIDADE CATÓLICA DO RIO DE JANEIRO

RUA MARQUÊS DE SÃO VICENTE, 225 - CEP 22453-900

RIO DE JANEIRO - BRASIL 


\title{
O JUIZ DE GARANTIAS E $O$ PROJETO DE LEI N' 8045/2010: A FUNÇÃO JURISDICIONAL NA INVESTIGAÇÃO PRELIMINAR À LUZ DA CONSTITUIÇÃO FEDERAL
}

\author{
por \\ PEDRO BRUZZI RIBEIRO CARDOSO
}

Monografia apresentada ao Departamento de Direito da Pontificia Universidade Católica do Rio de Janeiro (PUC-Rio) para a obtenção do Título de Bacharel em Direito.

Orientador: Sergio Chastinet Duarte Guimarães. 


\section{DEDICATÓRIA}

Dedico este trabalho integralmente às pessoas que infelizmente não mais respiram o belo ar da primavera:

Às minhas bisavós maternas, que tanto me ensinaram e me moldaram como o homem que sou hoje.

À minha avó Julieta, por ter sido a matriarca de uma família unida e íntegra, que tanto me ensinou a importância dos laços familiares.

À minha sogra Sirinéa, pela sua partida precoce. 


\section{AGRADECIMENTOS}

É tarefa árdua poder incluir com a necessária brevidade todas as pessoas responsáveis por essa caminhada de 05 anos.

Primeiramente, agradeço aos meus pais por todo incentivo em mudar de São José dos Campos/SP para o Rio de Janeiro/RJ tão somente para cursar Direito na PUC-Rio. Vocês não imaginam o quanto essa jornada me acresceu como pessoa e como profissional do direito.

Aos meus avós maternos Sergio e Vânia, por todo apoio logístico, financeiro e moral para enfrentar essa empreitada. Sem vocês, acredito que nada disso poderia ter acontecido.

À minha irmã, que tanto batalhou comigo nos primeiros anos no Rio de Janeiro, e hoje segue seu rumo como Auditora Fiscal do Estado de Santa Catarina.

Ao meu tio Luis André, por todos os ensinamentos e por provar que o cargo que ocupamos não define nosso caráter.

Ao professor Pedro Marcos, por acender em mim uma paixão sem romantismos pelo direito.

Ao meu orientador, professor Sergio Duarte, por me mostrar como podemos ser ao mesmo tempo um grande professor, advogado, jurista e, ainda assim, ser uma pessoa humilde e leve.

Aos professores Leonardo Chaves, Salvador Bermeguy, Victoria Sulocki, Adriano Barcelos, Adolfo Borges, por todos os ensinamentos.

Aos defensores Marcelo Pedrosa, Leonardo Guida, Felipe Almeida, Denis Sampaio e Antônio José por me mostrarem a grandeza da Defensoria Pública e da defesa criminal dos mais vulneráveis.

Às advogadas Marcia Dinis e Sheila Lustoza, por me introduzirem à advocacia criminal e me demonstrarem que, parafraseando Sobral Pinto, a advocacia criminal não é para covardes.

Por fim, à minha namorada Júlia Ravanelli, por todo apoio e por todas as batalhas vencidas conjuntamente. 


\section{RESUMO}

A presente monografia tem por objeto trazer à baila um estudo acerca da figura do juiz de garantias, tal qual disposto no Projeto de Lei $\mathrm{n}^{\circ}$ $8045 / 2010$, e como tal figura, uma vez instituída em nosso ordenamento pátrio, poderá trazer à constitucionalização de nosso processo penal, gerando uma maior observância dos direitos e garantias fundamentais, mormente no que tange à investigação preliminar. Para tanto, necessário fazer uma análise da atual conjuntura da função do juiz na investigação preliminar, bem como dos dispositivos do diploma processual penal que aparentam não terem sido recepcionados pela Constituição Federal de 1988. Após, será realizada uma análise detalhada dos princípios constitucionais e como eles se relacionam com a seara processual penal, notadamente em sua fase administrativa preliminar. Depois de uma análise meticulosa no panorama constitucional, será detalhado minuciosamente o funcionamento da figura do juiz de garantias, com todos seus benefícios e suas pertinentes críticas, o atual trâmite do Projeto de Lei responsável por sua instituição e, por último, uma análise do direito comparado europeu e latino-americano com enfoque nos países que buscaram instituir a sua figura e/ou criar um sistema processual penal mais próximo do sistema acusatório, com maior enfoque na manutenção da imparcialidade do juízo.

\section{PALAVRAS-CHAVE}

Constitucionalização do processo penal - Devido processo legal Sistema acusatório - Imparcialidade do juiz - Investigação Preliminar Juiz de Garantias - Projeto de Lei 8045/2010 - Função na investigação preliminar - Afastamento do juiz contaminado. 


\section{SUMÁRIO}

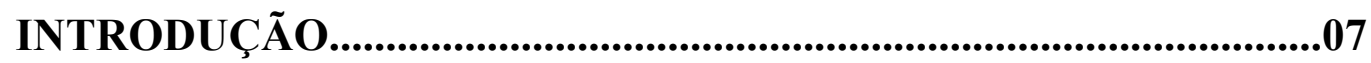

CAPÍTULO 1. SISTEMAS PROCESSUAIS......................................12

1.1. Sistema Inquisitivo ou Inquisitório.............................................13

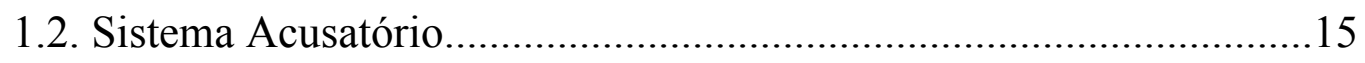

1.3 Sistema Acusatório Misto................................................................17

CAPÍTULO 2. PRINCÍPIOS PROCESSUAIS PENAIS.......................22

2.1. Devido Processo Legal...................................................................23

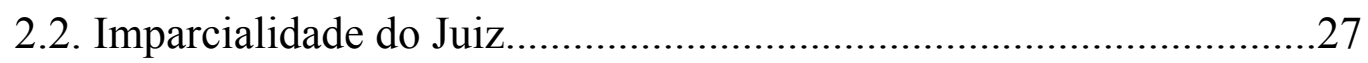

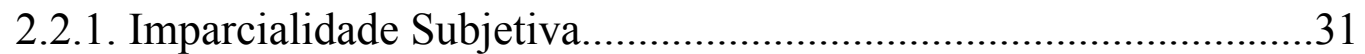

2.2.2. Imparcialidade Objetiva.................................................................

CAPÍTULO 3. A FIGURA DO JUIZ DE GARANTIAS........................35

3.1. A Atual Função do Juiz na Investigação Preliminar.............................35

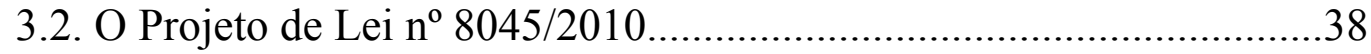

3.3. Objetivos do Juiz de Garantias..........................................................

3.3.1. A Função na Investigação Preliminar...............................................43

3.3.2. Otimização da Investigação e Instrução Processual..........................47

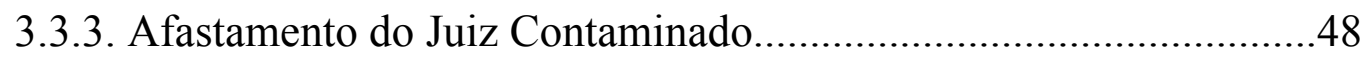

3.4. Aspectos Controvertidos do Juiz de Garantias....................................52

3.5. O Atual Trâmite do Projeto de Lei $n^{0} 8045 / 2010 \ldots \ldots \ldots \ldots \ldots \ldots \ldots \ldots \ldots \ldots \ldots \ldots . . .57$

3.6. Países que Adotam a Figura do Juiz de Garantias...............................60

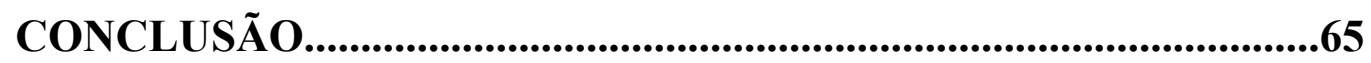

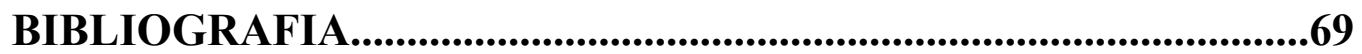




\section{LISTA DE ABREVIAÇÕES}

PLS - Projeto de Lei do Senado

PL - Projeto de Lei

CRFB/88 - Constituição da República Federativa do Brasil de 1988

CPP - Código de Processo Penal

TEDH - Tribunal Europeu de Direitos Humanos

IP - Inquérito Policial

PIC - Procedimento Investigatório Criminal

STF - Supremo Tribunal Federal

STJ - Superior Tribunal de Justiça

RISTF - Regimento Interno do Supremo Tribunal Federal

RISTJ - Regimento Interno do Superior Tribunal de Justiça

CNJ - Conselho Nacional de Justiça 


\section{INTRODUÇÃO}

O presente tema visa aproximar a investigação preliminar realizada no Brasil com os ditames expostos na Constituição da República Federativa do Brasil de 1988, para tanto, analisando o PLS 156/2009 de iniciativa do Senado Federal, atualmente em trâmite perante a Câmara dos Deputados sob o registro de PL $n^{\circ} 8045 / 2010$, que institui a função do "Juiz de Garantias" na fase preliminar do processo penal brasileiro.

A mudança legislativa que o novo Projeto de Lei visa realizar se irradia em todo o campo do Processo Penal. Contudo, no trabalho em comento, a abordagem será feita tão somente sobre a figura do juiz de garantias e sua aplicação na fase preliminar, sem desconsiderar, entretanto, as consequências que essa mudança de paradigma causará na fase seguinte da persecução criminal, as quais serão trazidas à baila de maneira perfunctória.

O cerne da questão é bem simples: O Código de Processo Penal atualmente vigente no país realiza os comandos normativos presentes na $\mathrm{CRFB} / 88$, principalmente no que tange ao sistema acusatório, às garantias, princípios e direitos fundamentais dos cidadãos submetidos á investigação preliminar?

Segundo Fauzi Hassan Choukr, apesar do Código de Processo Penal ter sobrevivido às mudanças de diversas constituições, com a promulgação da Constituição Federal de 1988, que trouxe o modelo acusatório e inúmeros princípios processuais, temos "de um lado o texto constitucional com os valores acima mencionados; por outro o Código de Processo Penal, com seus resquicios inquisitivos". ${ }^{1}$

\footnotetext{
${ }^{1}$ CHOUKR, Fauzi Hassan. Brasil. In: MAIER, Julio B. J.; AMBOS, Kai; WOISCHNIK, Jan (Orgs.). Las reformas procesales penales en América Latina. Buenos Aires: Ad-Hoc, 2000. p. 123.
} 
Continua sua exposição alegando que a "Constituição de 1.988 adotou o modelo acusatório para o processo penal brasileiro, onde estão presentes os princípios fundamentais, sobretudo inseridos no artigo 5."2

Tendo em vista que nosso diploma processual penal vigente (Decreto-Lei N $\mathrm{N}^{\mathrm{o}} 3689$ de 03 de outubro de 1941) foi concretizado após o golpe de 1937 e a implantação do Estado Novo $^{3}$, não é forçoso concluir que possui sua raiz em um momento político autoritário e de privação de direitos e garantias fundamentais.

Nesse norte, salienta Aramis Nassif que:

"Inevitável reportar à origem do Código de Processo Penal que, mesmo com o passar do tempo e o momento democrático que vive o país, mantém algumas características ideológicas originais. Não se discute que o diploma adjetivo brasileiro teve sua inspiração no Código Rocco, vigente durante o governo de Mussolini na Itália, então um Estado fascista". ${ }^{4}$

Muito se pode concluir sobre o momento político de um país a partir de sua política criminal. Outrossim, em um momento democrático vemos a prevalência dos direitos do indivíduo perante a sociedade, enquanto que em um momento autoritário vemos a prevalência da sociedade sobre o indivíduo, com a consequente privação e/ou mitigação dos direitos do indivíduo pelo bem comum. É exatamente nessa tenda que o Código de Processo Penal se insere em 1941 no Brasil.

Não é necessária muita divagação para confirmar a matriz autoritária do diploma. Temos, pois, na exposição de motivos do CPP, a seguinte explanação:

"De par com a necessidade de coordenação sistemática das regras do processo penal num Código único para todo o Brasil, impunha-se o seu ajustamento ao objetivo de maior eficiência e energia da ação repressiva do Estado contra os que delinquem. As nossas vigentes leis de processo penal asseguram aos réus, ainda que colhidos em flagrante ou confundidos pela evidencia das provas, um tão extenso catálogo de garantias e favores, que a repressão se torna, necessariamente, defeituosa e retardatária, decorrendo daí um indireto estímulo à expansão da criminalidade. Urge que seja abolida a injustificável primazia do

\footnotetext{
${ }^{2}$ Ibid. p. 124.

${ }^{3}$ PRADO, Geraldo. Sistema acusatório: a conformidade constitucional das leis processuais penais. 4. ed. Rio de Janeiro: Lumen Juris, 2006. p. 171.

${ }^{4}$ NASSIF, Aramis. Sistema processual penal brasileiro: a nostalgia autoritária. In: AZEVEDO E SOUZA, Bernardo de; SILVEIRA, Felipe Lazzari da (Orgs.). Democracia e(m) sistema penal. Porto Alegre: Canal Ciências Criminais, 2017. p. 84.
} 
interesse do indivíduo sobre o da tutela social. Não se pode continuar a contemporizar com pseudodireitos individuais em prejuízo do bem comum." ${ }^{5}$

Por isso, nos ensina Aury Lopes que é necessário ocorrer a democratização do processo penal pela Constituição, por ser medida de evolução do direito, vez que em um Estado Democrático de Direito não há de se "tolerar um processo penal autoritário e típico de um Estadopolicial, pois o processo penal deve adequar-se à Constituição e não viceversa."

Não à toa, demonstra ser a decisão mais acertada, ao contrário de mudanças pontuais em um código retrógrado e antagônico com a Constituição Federal, a implementação de um Novo Codex Processual Penal, para uma melhor adequação com o sistema acusatório e com os princípios explícitos e implícitos da Carta, dentre eles, destacam-se o princípio da dignidade da pessoa humana, devido processo legal, da imparcialidade do juiz e da ampla defesa.

É exatamente dentro do bojo da implementação de um novo Código de Processo Penal que surge o objeto do presente estudo, a partir do PLS 165/2009 do Senado Federal, hoje PL nº 8045/2010 da Câmara dos Deputados.

Com efeito, evoca o PL o instituto do juiz de garantias como figura elementar para a efetivação do sistema acusatório, garantindo assim a devida imparcialidade do juiz quando do julgamento da causa, concretizando o devido processo legal em nossa jurisdição penal.

O necessário afastamento do juiz das funções investigatórias não é bem observada pela atual legislação, uma vez que há inúmeros dispositivos que possibilitam a atuação ex officio do juiz. ${ }^{7}$ Tendo como

\footnotetext{
${ }^{5}$ MIRABETE, Julio Fabbrini. Código de processo penal interpretado: referências doutrinárias, indicações legais, resenha jurisprudencial. 9. ed. atual. São Paulo: Atlas, 2002. p. 55/56.

${ }^{6}$ LOPES JUNIOR, Aury. Introdução crítica ao processo penal: fundamentos da instrumentalidade constitucional. 4. ed. Rio de Janeiro: Lumen Juris, 2006. p. 40.

${ }^{7}$ A título meramente exemplificativo, destacam-se os artigos 156, 196, 225, 242, todos do Código de Processo Penal.
} 
exemplo, observa-se a possiblidade de instauração de inquérito policial a partir de requisição da Autoridade Judiciária. ${ }^{8}$

Geraldo Prado, ao falar sobre a (im)possibilidade do juiz que requisitou a instauração do inquérito policial julgar a causa, por estar impedido, destaca que:

“o réu não poderá confiar em um juiz que, independentemente de qualquer causa penal, já se manifestou a princípio pela existência de uma infração penal, ainda que ao nível de um juízo sumário (...) De fato, nestas circunstâncias, poderá haver inversão do ônus da prova, com o réu se sentindo impelido a demonstrar que o juiz inicialmente não tinha razão". ${ }^{9}$

Ademais, sobre o mesmo dispositivo, alegando violação ao sistema acusatório, Eugênio Pacelli indaga que "Temos, pois, como não recebida, a disposição que permite ao juiz a requisição de inquérito policial"' ${ }^{10}$

A atuação do magistrado na fase preliminar é necessária sobretudo no que toca aos incidentes que clamam por cláusula de reserva de jurisdição. Nesse sentido, Aury Lopes preleciona que "Esta é a posição que o juiz deve adotar quando chamado a atuar no inquérito policial: como garante dos direitos fundamentais do sujeito passivo". 11

Contudo, tal atuação não pode comprometer o futuro julgamento do processo, contaminando o juiz de pré-conceitos ou pré-juízos a partir de elementos colhidos na investigação, uma vez ser necessária que sua imparcialidade seja mantida intacta.

Nesse norte, entra a figura do Juiz de Garantias para trazer o necessário afastamento do magistrado contaminado pela resolução dos incidentes na fase da investigação preliminar do processo de conhecimento.

\footnotetext{
${ }^{8}$ Art. $5^{\circ}$ Nos crimes de ação pública o inquérito policial será iniciado: (...) II - mediante requisição da autoridade judiciária ou do Ministério Público, ou a requerimento do ofendido ou de quem tiver qualidade para representá-lo.

${ }^{9}$ PRADO, Geraldo. Op. cit., p. 111.

${ }^{10}$ PACELli, Eugênio; FISCHER, Douglas. Comentários ao Código de Processo Penal e sua Jurisprudência. 7. ed. São Paulo: Atlas, 2015. p. 24.

${ }^{11}$ LOPES JUNIOR, Aury. Sistemas de Investigação preliminar no processo penal. 4. ed. Rio de Janeiro: Lumen Juris, 2006. p. 171.
} 
Para exposição do tema, o primeiro capítulo tratará sobre os diferentes tipos de sistemas processuais, atento com a evolução da sistemática até o alcance do sistema acusatório por excelência, sem contudo desconsiderar as particularidades do sistema processual penal vigente em nosso ordenamento jurídico.

O segundo capítulo fornecerá uma visão sobre os princípios que efetivam os direitos e garantias individuais percebidos pelos cidadãos no momento da investigação preliminar, já traçando preliminarmente a consequência da implementação da figura do juiz de garantias para com esses princípios.

Adentrando ao conceito e aplicação do juiz de garantias, o terceiro capítulo trará a análise do PL n ${ }^{\circ} 8045 / 2010$, sua definição, função e toda a problemática que envolve o tema do juiz de garantias, ressaltando a posição defendida nesse trabalho de sua aplicabilidade, trazendo, no entanto, as pertinentes críticas sobre o tema, para um possível aperfeiçoamento do instituto. Por fim, far-se-á uma breve explanação sobre o atual trâmite do novo CPP, responsável por sua implementação no ordenamento pátrio, bem como uma análise do instituto em outros países, particularmente os europeus e latino-americanos. 


\section{CAPÍTULO 1. SISTEMAS PROCESSUAIS PENAIS}

Os sistemas processuais penais são consequências ou reflexos diretos da regulamentação do processo penal em determinados momentos da história. ${ }^{12}$

Isso porque, segundo Paulo Rangel:

"sistema processual penal é o conjunto de princípios e regras constitucionais, de acordo com o momento político de cada Estado, que estabelece as diretrizes a serem seguidas à aplicação do direito penal a cada caso concreto". ${ }^{13}$

Por isso, os sistemas processuais penais são os espelhos das exigências para a aplicação do direito penal de cada Estado em uma determinada época. ${ }^{14}$

Ademais, o momento político e econômico que a sociedade se encontrava inserida é exame necessário para a constatação de cada sistema, uma vez que requer uma análise do contexto espaço-temporal em que se encontra inserto. ${ }^{15}$

Por representar diferentes momentos históricos, há a ocorrência de mais de um sistema processual penal, e até mesmo características diferentes dentro de um mesmo sistema. Por isso, Mauro Fonseca Andrade explicita:

"de fato é possível observar que vários elementos, que hoje estão presentes em um determinado sistema processual penal, não necessariamente o configuravam em seu início. Isso bem demonstra a mutabilidade a que os sistemas processuais estão sujeitos, sem que percam essa condição e os nomes que os caracterizam". ${ }^{16}$

Serão abordados no presente estudo os 03 (três) principais sistemas processuais penais, que de acordo com Mirabete:

\footnotetext{
${ }^{12}$ ANDRADE, Mauro Fonseca. Sistemas processuais penais e seus principios reitores. Curitiba: Juruá, 2008. p. 37.

${ }^{13}$ RANGEL, Paulo. Direito Processual Penal. 18. ed. Rio de Janeiro: Lumen Juris, 2010. p. 49.

${ }^{14}$ LOPES JUNIOR, Aury. Fundamentos do Processo Penal: Introdução Crítica. 3. ed. São Paulo: Saraiva, 2017. p. 157. Livro digital.

${ }^{15}$ PRADO, Geraldo. Op. cit., p. 61.

${ }^{16}$ ANDRADE, Mauro Fonseca. Sistemas processuais penais e seus princípios reitores. Curitiba: Juruá, 2008. p. 37.
} 
"Segundo as formas com que se apresentam e os princípios que os informam são três os sistemas processuais utilizados na evolução histórica do direito: o inquisitivo, o acusatório e o misto"17.

Com efeito, pode-se inferir que se tratam de três sistemas teóricos ou abstratos, que nos permite, contudo, entender e analisar a aplicação dos sistemas in concreto. ${ }^{18}$

\subsection{SISTEMA INQUISITIVO OU INQUISITÓRIO}

O sistema inquisitivo ou inquisitório representou um grande hiato temporal de nossa história, percorrendo desde o século XIII até o século XVIII $^{19}$, tendo como grande marco histórico o Tribunal da Inquisição ou Santo Ofício, instituído no século XIII pela Igreja Católica para julgar questões relacionadas aos Mandamentos da Igreja Católica. ${ }^{20}$

No dito sistema, há a confusão na figura do juiz, eis que não há a função de acusador e julgador separadamente, e sim uma unicidade dos dois misteres na figura do juiz inquisidor. ${ }^{21}$

Por isso, nos tempos da Idade Média e no bojo da Igreja Católica, Jacinto Nelson Miranda Coutinho destaca que " $O$ controle direto do processo penal pelos clérigos exclui, por conveniência, um órgão acusador: o actus trium personarum já não se sustenta". ${ }^{22}$

Fato é que o sistema inquisitivo possui diversas peculiaridades próprias de sua estrutura. Paulo Rangel destaca alguma dessas peculiaridades:

“a) as três funções (acusar, defender e julgar) concentram-se nas mãos de uma só pessoa, iniciando o juiz, ex officio, a acusação quebrando, assim, sua imparcialidade; b) o processo é regido pelo sigilo, de forma secreta, longe dos olhos do povo; c) não há contraditório nem a ampla defesa, pois o acusado é

\footnotetext{
${ }^{17}$ MIRABETE, Julio Fabbrini. Processo Penal. 2. ed. São Paulo: Atlas, 1992. p. 41.

${ }^{18}$ FEITOZA, Denilson. Direito processual penal: teoria, crítica e práxis. 7. ed. Niterói, RJ: Impetus, 2010. p. 60.

${ }^{19}$ Ibid. p. 41.

${ }^{20}$ LOPES JUNIOR, Aury. Fundamentos do Processo Penal: Introdução Crítica. 3. ed. São Paulo: Saraiva, 2017. p. 167/168. Livro digital.

${ }^{21}$ CONFIM, Edilson Mougenot. Curso de processo penal. 7. ed. São Paulo: Saraiva, 2012. p. 68.

${ }^{22}$ COUTINHO, Jacinto Nelson Miranda. Crítica à teoria geral do direito processual penal. Rio de Janeiro: Renovar, 2001. p. 23.
} 
mero objeto do processo e não sujeito de direitos, não se lhe conferindo nenhuma garantia; d) o sistema de provas é o da prova tarifada ou prova legal, e, consequentemente, a confissão é a rainha das provas." 23

Nessa mesma linha de Rangel, destacam-se os posicionamentos de Aury Lopes ${ }^{24}$, Mirabete ${ }^{25}$ e Geraldo Prado ${ }^{26}$, ainda que com alguns pontos a mais e outros a menos sobre a matéria.

Interessante aspecto sobre o sistema inquisitivo é trazido por Jacinto Nelson Miranda Coutinho que, apesar de elencar basicamente as mesmas características aduzidas pelos outros autores, como a falta de contraditório e a concentração de todas as figuras na figura do juiz, vai adiante ao salientar:

"A característica fundamental do sistema inquisitório, em verdade, está na gestão da prova, confiada essencialmente ao magistrado, que, em geral, no modelo em análise, recolhe-a secretamente (...) Afastado do contraditório e sendo o senhor da prova, sai em seu encalço guiado essencialmente pela visão que tem (ou faz) do fato." 27

Por fim, impende destacar que ainda que haja um sistema inquisitório com todas suas peculiaridades, há uma impropriedade ao usar o termo processo inquisitório, uma vez que suas características não coadunam com a de um verdadeiro processo, pela falta da figura do

\footnotetext{
${ }^{23}$ RANGEL, Paulo. Op. cit., p. 50.

24 "O sistema inquisitório muda a fisionomia do processo de forma radical. (...) confundem-se as atividades do juiz e acusador, e o acusado perde a condição de sujeito processual e se converte em mero objeto de investigação. Frente a um fato típico, o julgador atua de ofício, sem necessidade de prévia invocação, e recolhe (também de ofício) o material que vai construir seu convencimento. O processado é a melhor fonte de conhecimento e, como se fosse uma testemunha, é chamado a declarar a verdade sob pena de coação. (...) O juiz atua como parte, investiga, dirige, acusa e julga. Com relação ao procedimento, sói ser escrito, secreto e não contraditório.” LOPES JUNIOR, Aury. Fundamentos do Processo Penal: Introdução Crítica. 3. ed. São Paulo: Saraiva, 2017. p. 166/167. Livro digital.

25 "No sistema inquisitivo (....) inexistem regras de igualdade e liberdade processuais, o processo é normalmente escrito e secreto e se desenvolve em fases por impulso oficial, a confissão é elemento suficiente para a condenação, permitindo-se inclusive a tortura etc.". MIRABETE, Julio Fabbrini. Processo Penal. 2. ed. São Paulo: Atlas, 1992. p. 41.

26 "as características marcantes da Inquisição foram a forma escrita, em contraposição à oralidade, o segredo, confrontando a publicidade e a iniciativa do juiz para o procedimento (...) a tortura impunha-se como procedimento de investigação baseado no conhecimento, meio, portanto, considerado à época o mais evoluído. A prisão durante o processo torna-se a regra, firme na tese de que todo acusado obstaculiza a investigação da verdade." PRADO, Geraldo. Op. cit., p. 82/83.

${ }^{27}$ COUTINHO, Jacinto Nelson Miranda. Op. cit., p. 24.
} 
contraditório, juiz imparcial e igualdade, sendo, outrossim, um contrassenso o uso deste termo. ${ }^{28}$

\subsection{SISTEMA ACUSATÓRIO}

Em contraposição ao sistema inquisitivo acima mencionado, tem-se o sistema acusatório, que:

"vigorou durante quase toda a Antiguidade grega e romana, bem como na Idade Média, nos domínios do direito germano. A partir do século XIII, entra em declínio, passando a ter prevalência o sistema inquisitivo. Atualmente, o processo penal inglês é o que mais se aproxima de um sistema acusatório puro." 29

Fato é que nos meandros dos séculos XVII e XVIII, irradiados pelo iluminismo e com um novo período de administração da justiça, o sistema inquisitório foi sendo paulatinamente superado ${ }^{30}$, muito influenciado, portanto, pelo momento político vivido nesta época.

Neste norte, Geraldo Prado assinala:

“A transição política e cultural da monarquia para a República teve repercussão no campo do processo penal, por meio da abolição da tortura e da adoção de um sistema processual penal inspirado nos aplicados pela Roma Republicana e pela Inglaterra." 31

Aos poucos, com a derrocada dos governos autoritários, foi novamente se instalando um sistema processual penal mais compatível com as garantias e direitos individuais dos cidadãos, trazendo à lúmen algumas figuras muito importantes para a ocorrência de um processo verdadeiro. $^{32}$

Podem-se destacar como principais elementos do sistema acusatório o respeito ao contraditório e ampla defesa, a ocorrência da figura do juiz imparcial com a devida separação entre as partes

\footnotetext{
${ }^{28}$ CONFIM, Edilson Mougenot. Op. cit., p. 69/70.

${ }^{29}$ LIMA, Renato Brasileiro de. Manual de processo penal. Niterói, RJ: Impetus, 2011. p. 06.

${ }^{30}$ PRADO, Geraldo. Op. cit., p. 90.

${ }^{31}$ Ibid. p. 91.

${ }^{32}$ CONFIM, Edilson Mougenot. Op. cit., p. 70.
} 
processuais, a publicidade e oralidade da instrução, assim como a devida inércia do juiz na sua atuação ex officio. ${ }^{33}$

Conforme observado por Mirabete:

"No direito moderno, tal sistema implica o estabelecimento de uma verdadeira relação processual com o actum trium personarum, estando em pé de igualdade o autor e o réu, sobrepondo-se a eles, como órgão imparcial de aplicação da lei, o juiz". ${ }^{34}$

Também, no mesmo sentido, Marcellus Polastri Lima ${ }^{35}$ e Renato Brasileiro de Lima $^{36}$ indagam que somente com o sistema acusatório, houve o respeito à figura do actum trium personarum.

Das características marcantes do sistema acusatório, pode-se delinear também:

“a) contraditório, como garantia político-jurídica do cidadão; b) as partes acusadora e acusada, em decorrência do contraditório, encontram-se no mesmo pé de igualdade; c) o processo é publico, fiscalizável pelo olho do povo, excepcionalmente permite-se uma publicidade restrita ou especial; d) as funções de acusar, defender e julgar são atribuídas a pessoas distintas e, logicamente, não é dado ao juiz iniciar o processo (ne procedat judex ex officio); e) o processo pode ser oral ou escrito; f) existe, em decorrência do contraditório, igualdade de direitos e obrigações entre as partes, pois non debet licere actori, quod reo non permittitur; g) a iniciativa do processo cabe à parte acusadora, que poderá ser o ofendido ou seu representante legal, ou qualquer cidadão do povo ou um órgão do Estado." ${ }^{37}$

Uma última importante característica é a gestão da prova no sistema acusatório: aqui, as partes são responsáveis pela sua gestão, cabendo ao juiz, ao contrário do sistema inquisitivo, a função de respeito aos direitos e garantias fundamentais, de modo a manter as regras do jogo processual respeitadas $^{38}$, assim como de julgar a partir do seu livre convencimento, sem a ocorrência da prova tarifada. ${ }^{39}$

\footnotetext{
${ }^{33}$ LIMA, Renato Brasileiro de. Op. cit., p. 05/06.

${ }^{34}$ MIRABETE, Julio Fabbrini. Processo Penal. 17. ed. São Paulo: Atlas, 2005. p. 43.

35 "O sistema acusatório (...) se caracteriza pela existência do actum trium personarum". LIMA, Marcellus Polastri. Curso de Processo Penal: volume I. 3. ed. Rio de Janeiro: Lumes Juris, 2006. p. 32.

36 "O processo caracteriza-se, assim como legítimo actum trium personarum". LIMA, Renato Brasileiro de. Op. cit., p. 05.

${ }^{37}$ MIRABETE, Julio Fabbrini. Processo Penal. 17. ed. São Paulo: Atlas, 2005. p. 43/44.

${ }^{38}$ LIMA, Renato Brasileiro de. Op. cit., p. 05/06.

${ }^{39}$ LOPES JUNIOR, Aury. Fundamentos do Processo Penal: Introdução Crítica. 3. ed. São Paulo: Saraiva, 2017. p. 162. Livro digital.
} 
Alguns autores como Renato Brasileiro de Lima $^{40}$ e Marcellus Polastri Lima ${ }^{41}$, com algumas ressalvas, entendem que esse seria $\mathrm{o}$ sistema atualmente vigente no Brasil.

\subsection{SISTEMA ACUSATÓRIO MISTO}

Surge o referido modelo nos idos do século XIX na França. Sobre sua formação, Aury Lopes sublinha:

"Historicamente, o primeiro ordenamento jurídico que adotou esse sistema misto foi o francês, no Code d'Instruction Criminalle de 1808, pois foi o pioneiro na cisão das fases de investigação e juízo. Posteriormente, difundiu-se por todo o mundo e, na atualidade, é o mais utilizado." 42

Para parte da doutrina, o sistema que atualmente vigora no ordenamento jurídico pátrio é o sistema acusatório misto. Ou seja, possui uma natureza mista, com mitigações entre o sistema acusatório e inquisitório. $^{43}$

Isso porque nosso sistema está dividido entre uma etapa eminentemente inquisitiva, a saber, a fase preliminar de investigação (no qual estão inseridos o inquérito policial e o procedimento investigatório criminal), e uma etapa dotada das características do sistema acusatório, qual seja, a fase processual.

A fase preliminar adota elementos característicos do sistema inquisitivo. Segundo José Carlos Gonçalves Xavier de Aquino e José Renato Nalini “O investigatório policial é considerado inquisitório, pois

\footnotetext{
40 "Todavia, com o advento da Constituição Federal, que prevê de maneira expressa a separação das funções de acusar, defender e julgar, estando assegurado o contraditório e a ampla defesa, além do princípio da presunção de não culpabilidade, estamos diante de um sistema acusatório. É bem verdade que não se trata de um sistema acusatório puro". LIMA, Renato Brasileiro de. Op. cit., p. 07.

41 "E, considerando o caráter acusatório deferido ao processo penal pátrio pela Constituição de 1988, apesar da impureza do nosso Código de Processo Penal (...) pode-se falar hoje, como queria antigamente Frederico Marques, em um sistema acusatório puro." LIMA, Marcellus Polastri. Op. cit., p. 33/34.

${ }^{42}$ LOPES JUNIOR, Aury. Fundamentos do Processo Penal: Introdução Crítica. 3. ed. São Paulo: Saraiva, 2017. p. 174. Livro digital.

${ }^{43}$ PACELLI, Eugenio. Curso de Processo Penal. 21. ed. São Paulo: Atlas, 2017. p. 13/14.
} 
nele não funciona o advogado, é secreto e sigiloso. Não existe contraditório, pois este somente surge com o recebimento da denúncia. "44 Já na fase processual, observa-se a oralidade e publicidade, salvo em casos restritos de segredo de justiça. Ademais, observa-se a escolha do constituinte originário pela figura do Ministério Público para promover privativamente a ação penal pública, conforme vaticina o artigo 129, inciso I da $\mathrm{CF}^{45}$, o que demonstra a devida separação entre juiz e acusação.

A ampla defesa e o contraditório, que possuem assento constitucional e encontram-se no rol de direitos fundamentais protegidos por cláusula pétrea ${ }^{46}$, encontram-se presentes na fase instrutória. Há também a vedação à prática de tortura, ${ }^{47}$ mormente para a obtenção da confissão do investigado/acusado.

Paulo Rangel indica as principais características do sistema acusatório misto:

“a) a fase preliminar de investigação é levada a cabo, em regra, por um magistrado que, com o auxílio da polícia judiciaria, pratica todos os atos inerentes à formação de um juízo prévio que autorize a acusação (...) Há nítida separação entre as funções de acusar e julgar, não havendo processo sem acusação; b) na fase preliminar, o procedimento é secreto, escrito e o autor do fato é mero objeto de investigação, não havendo contraditório nem ampla defesa, face à influência do procedimento inquisitivo; c) a fase judicial é inaugurada com acusação penal feita, em regra, pelo Ministério Público, onde haverá um debate oral, público e contraditório, estabelecendo plena igualdade de direitos entre a acusação e a defesa; d) o acusado, na fase judicial, é sujeito de direitos e detentos de uma posição jurídica que lhe assegura o estado de inocência, devendo o órgão acusador demonstrar sua culpa, através do devido processo legal, e destruir este estado. O ônus é todo e exclusivo do Ministério Público; e) o procedimento na fase judicial é contraditório, assegurada ao acusado a ampla defesa, garantida a publicidade dos atos processuais e regido

\footnotetext{
${ }^{44}$ AQUINO, José Carlos Gonçalves Xavier; NALINI, José Renato. Manual de processo penal. 4. ed. São Paulo: Revista dos Tribunais, 2012. p. 42.

${ }^{45}$ Art. 129. São funções institucionais do Ministério Público: I - promover, privativamente, a ação penal pública, na forma da lei;: Importante lembrar que nas ações privadas, a capacidade para promover a ação privada compete ao ofendido, cônjuge, ascendente, descendente ou irmão, conforme artigo 100, $\S 2^{\circ}$ do Código Penal conjugado com artigo 31 do CPP.

${ }^{46}$ Art. $5^{\circ}$ Todos são iguais perante a lei, sem distinção de qualquer natureza, garantindo-se aos brasileiros e aos estrangeiros residentes no País a inviolabilidade do direito à vida, à liberdade, à igualdade, à segurança e à propriedade, nos termos seguintes: LV - aos litigantes, em processo judicial ou administrativo, e aos acusados em geral são assegurados o contraditório e ampla defesa, com os meios e recursos a ela inerentes;

${ }^{47}$ III - ninguém será submetido a tortura nem a tratamento desumano ou degradante;
} 
pelo princípio da concentração, em que todos os atos são praticados em audiência." 48

Imperioso trazer à baila algumas críticas pertinentes quanto ao uso da denominação de sistema acusatório "misto". Senão, veja-se.

Com críticas à conceituação de sistema acusatório misto, Gustavo Badaró afirma que "Atualmente não existem sistemas acusatórios ou inquisitórios "puros". Ora o processo é prevalentemente acusatório, ora apresenta maiores características inquisitoriais ${ }^{, 49}$,e termina afirmando que nosso atual sistema é prevalentemente acusatório, ainda que o juiz possua poderes instrutórios para produção de provas de ofício.

Todavia, conceituar o sistema processual brasileiro como acusatório misto ou prevalentemente acusatório não atesta ser o mais apropriado tecnicamente, tendo em vista a nítida prevalência de um sistema inquisitório, maquiado por um conceito eufemístico de acusatório misto.

Explica-se. A primeira falácia que deve ser abolida do imaginário de nosso sistema é a paridade de armas no processo penal. Ora, aqui a parte acusadora possui todo o aparato estatal para a investigação do crime, sendo certo que muita das vezes a Defesa técnica só toma ciência do feito uma vez que já formalizada a ação penal a partir do recebimento da denúncia e a consequente citação do acusado. ${ }^{50}$

Nesse giro, o uso do termo sistema misto é tão somente uma ginástica hermenêutica comum na doutrina nacional, quando na verdade o termo correto seria sistema (neo)inquisitório, em razão da possibilidade de

\footnotetext{
${ }^{48}$ RANGEL, Paulo. Op. cit., p. 55.

${ }^{49}$ BADARÓ, Gustavo Henrique Righi Ivahy. Processo Penal. 6. ed. São Paulo: Revista dos Tribunais, 2018. p. 101.

${ }^{50}$ Muitas das vezes os elementos informativos produzidos no inquérito ou PIC são utilizados como provas pelo juiz em sua sentença, ao arrepio do artigo 155 do CPP. Logo, acaba-se com a ampla defesa em fase judicial, uma vez que somente haverá a reprodução do já produzido na fase preliminar, sendo que nesta fase, não houve a participação da Defesa técnica.
} 
produção ex officio do juiz e pelo desrespeito ao contraditório do início ao fim do processo, incluindo aqui a fase preliminar de investigação. ${ }^{51}$

Na esteira dessa linha, Sheila Lovatti ressalta ser evidente que:

"havendo resquícios inquisitoriais no sistema, não há que classifica-lo de acusatório, tampouco de sistema misto, nomenclatura que busca colorir a escuridão do sistema inquisitivo, com características secundárias do sistema acusatório." ${ }^{, 52}$

A possibilidade de atuação do juiz ex officio no atual diploma processual, inclusive podendo determinar a prisão do acusado de ofício durante a instrução criminal, é um acinte para a separação das funções no processo de acusar e julgar.

Por isso, Denilson Feitoza faz uma importante provocação, ao destacar que:

"No cotidiano forense, é comum se afirmar que o sistema brasileiro é acusatório (...) Entretanto, um "observador externo" ao nosso sistema diria que nosso sistema não é acusatório, por ser marcadamente informado pelo princípio inquisitivo." 53

O que se observa é, nessa toada, que apesar de nossa Carta Magna explicitamente optar por um sistema processual incompatível com o inquisitório, ainda encontramos sua presença na legislação ordinária, doutrina, jurisprudência e práticas judiciárias. ${ }^{54}$

Logo, podemos observar que:

"Embora o modelo processual a partir dos acordos internacionais ratificados pelo Brasil, e da Constituição federal seja o acusatório, a legislação ordinária e as práticas judiciais ainda persistem nas matrizes inquisitoriais e totalitárias do processo penal." 55

Observa-se que dos pressupostos do sistema acusatório puro indicados no subcapítulo 1.2, o mais observado no ordenamento jurídico é

\footnotetext{
${ }^{51}$ LOPES JUNIOR, Aury. Fundamentos do Processo Penal: Introdução Crítica. 3. ed. São Paulo: Saraiva, 2017. p. 173/178. Livro digital.

${ }^{52}$ LOVATTI, Sheila Mayra Lustoza de Souza. Justiça penal negociada. Rio de Janeiro: Gramma, 2017. p. 111.

${ }^{53}$ FEITOZA, Denilson. Op. cit., p. 64.

${ }^{54}$ GIACOMOLLI, Nereu José. O devido processo penal: abordagem conforme a Constituição Federal

e o Pacto de São José da Costa Rica. 3. ed. São Paulo: Atlas, 2016. p. 95/96.

${ }^{55}$ Ibid. p. 97.
} 
o da publicidade do processo. Posto isso, é inevitável a conclusão de que nosso sistema muito mais se assemelha com o sistema inquisitivo do que com o sistema acusatório, devendo, portanto, ser denominado de sistema neoinquisitivo, e não maquiado pelo comedimento de sistema acusatório misto ou impuro. 


\section{CAPÍTULO 2. PRINCÍPIOS PROCESSUAIS PENAIS}

Para uma correta compreensão do tema em comento, mister ressaltar alguns princípios que norteiam o processo penal pátrio, para assim concluir de uma maneira mais efetiva a mudança paradigmática que a figura do juiz de garantias poderá trazer para o ordenamento jurídico.

Com a promulgação da CRFB de 1988, houve a constitucionalização de todas as áreas do direito, de modo que todo o ordenamento jurídico prévio e posterior à Constituição devem ser interpretados conforme a nova Carta Magna, sob pena de não recepção ou inconstitucionalidade, respectivamente.

Significa dizer, em sentido amplo, que toda ordem jurídica infraconstitucional deve ser interpretada sob a luz dos princípios e regras da Constituição. ${ }^{56}$

Isso porque a Constituição, segundo Thomas Cooley, pode ser definida como sendo "o corpo de regras e princípios, em conformidade com os quais são normalmente exercidos os poderes da soberania."

Com efeito, não pode ser compreendido o processo penal brasileiro sem o entendimento dos princípios constitucionais que o regem, principalmente levando em consideração as (in)compatibilidades das normas processuais com a nossa constituição.

Conforme salienta Luiz Flavio Gomes, os princípios:

"não são apenas um conjunto de valores ou de prescrições éticas ou programáticas. São normas jurídicas de caráter cogente. De outro lado, a eficácia prática dos princípios irradia-se não só ao momento legislativo de elaboração da norma penal (quando o legislador cria a lei penal), senão também ao aplicativo e interpretativo (nem o intérprete nem o juiz podem ignorá-los)". ${ }^{58}$

\footnotetext{
${ }^{56}$ SARLET, Ingo Wolfgang; MARINONI, Luiz Guilherme; MITIDIERO, Daniel Francisco. Curso de direito constitucional. São Paulo: Revista dos Tribunais, 2012. p. 82/83.

${ }^{57}$ COOLEY, Thomas M. Principios gerais de direito constitucional nos Estados Unidos da América. Campinas: Russell \& Russell, 2002. p. 33.

${ }^{58}$ GOMES, Luiz Flavio; BIANCHINI, Alice; DAHER, Flávio. Princípios Constitucionais Penais: à luz da Constituição e dos Tratados Internacionais. LivroeNet/Atualidades do Direito, 2015. p. 08. Livro digital.
} 
É bem verdade que há uma maior relevância nos bens tutelados pelo processo penal - no qual se destaca a liberdade -, por isso mesmo que se mostra necessário que a Constituição disponha sobre os princípios basilares, de modo a garantir a rigidez constitucional. ${ }^{59}$

Nesse mesmo norte, Aury Lopes pondera que nossa Carta Maior "escolheu a estrutura democrática sobre a qual há que existir e se desenvolver o processo penal, forçado que está - pois modelo préconstituição de 1988 - a adaptar-se e conformar-se a esse paradigma" ${ }^{60}$

Outrossim, tendo em vista o caráter cogente dos princípios e a necessária filtragem constitucional imposta ao Código de Processo Penal, tanto o princípio do devido processo legal, quanto o princípio da imparcialidade do juiz serão delineados abaixo.

\subsection{DEVIDO PROCESSO LEGAL}

O princípio do devido processo legal é visto pela primeira vez nos idos do século XIII na Inglaterra, após um acordo do então Rei João Sem Terras e os barões do país, acordo este que gerou um documento denominado de Magna Carta ${ }^{61}$.

Diz a disposição 39 da referida Carta:

"39 - Nenhum homem livre será detido ou aprisionado, ou privado de seus direitos ou bens, ou declarado fora da lei, ou exilado, ou despojado, de algum modo, de sua condição; nem procederemos com força contra ele, ou mandaremos outros fazê-lo, a não ser mediante o legítimo julgamento de seus iguais e de acordo com a lei da terra." ${ }^{62}$

Nos dizeres de Nereu José Giacomolli, na origem do processo devido legal "percebe-se, claramente, a função limitativa do poder

\footnotetext{
${ }^{59}$ JARDIM, Afrânio Silva. Direito Processual Penal. 11. ed. Rio de Janeiro: Forense, 2007. p. 307.

${ }^{60}$ LOPES JUNIOR, Aury. Fundamentos do Processo Penal: Introdução Crítica. 3. ed. São Paulo: Saraiva, 2017. p. 34. Livro digital.

${ }^{61}$ JORGE, Estêvão Luís Lemos. O contraditório no inquérito policial: à luz dos princípios constitucionais. Campinas, SP: Millennium Editora, 2015. p. 27.

62 CARTA, Magna. (Magna Charta Libertatum). Disponível em $<$ http://www4.policiamilitar.sp.gov.br/unidades/dpcdh/Normas_Direitos_Humanos/MAGNA\%2 0CARTA\%20-\%20PORTUGU\%C3\%8AS.pdf>. Acesso em 27 mar. 2019.
} 
estatal frente aos particulares e a perspectiva de adoção do Estado de Direito (Government under Law). "63

Muito tempo após, a cláusula do due process of law também foi incorporada à Constituição dos Estados Unidos da América ${ }^{64}$, notadamente em sua emenda XIV, que assim dispõe:

"Seção 1. Todos os indivíduos nascidos ou naturalizados nos Estados Unidos, e submetidos à sua jurisdição, são cidadãos dos Estados Unidos e do Estado onde residem. Nenhum Estado fará ou aplicará qualquer lei que restrinja os privilégios ou imunidades dos cidadãos dos Estados Unidos; nenhum Estado privará qualquer pessoa da vida, da liberdade ou da propriedade, sem o devido procedimento legal, nem negará a qualquer pessoa dentro de sua jurisdição a proteção equitativa das leis". ${ }^{5}$

Já no contexto brasileiro, teve sua incorporação na CRFB/88 dentro do rol de direitos fundamentais ${ }^{66}$, demonstrando a importância que o constituinte originário versou sobre o tema.

Por isso, Johnny Wilson Batista Guimarães indaga:

"Entre os ramos do Direito atingidos pela colisão com o conjunto principiológico da $\mathrm{CF} / 88$, o Processo Penal, ligado de forma umbilical à realização das liberdades e espelho do estágio de evolução civilizatória de uma nação, tem merecido destaque, não restando margem para a fuga da influência constitucionalizante. Basta, neste ponto, atentar para os incisos LIV (due process of law)" ${ }^{67}$

Pela sua importância para a garantia da ordem constitucional no processo penal, Renato Marcão ressalta:

"É preciso admitir que esse princípio alcança todo o sistema processual, de modo a estabelecer relações com cada fase do processo e com outros tantos princípios incidentes." ${ }^{, 68}$

E segue o autor afirmando que uma vez instaurado o processo, todos os trâmites legais devem ser observados, posto que não existe

\footnotetext{
${ }^{63}$ GIACOMOLLI, Nereu José. Op. cit., p. 98/99.

${ }^{64}$ Ibid. p. 99.

${ }^{65}$ ESTADOS UNIDOS DA AMÉRICA. Constituição dos Estados Unidos da América. Disponível em <http://corvobranco.tripod.com/dwnl/constEUA.pdf>. Acesso em 27 mar. 2019.

${ }^{66}$ Art. $5^{\circ}$ Todos são iguais perante a lei, sem distinção de qualquer natureza, garantindo-se aos brasileiros e aos estrangeiros residentes no País a inviolabilidade do direito à vida, à liberdade, à igualdade, à segurança e à propriedade, nos termos seguintes: LIV - ninguém será privado da liberdade ou de seus bens sem o devido processo legal;

${ }^{67}$ GUIMARÃES, Johnny Wilson Batista. Imputação criminal preliminar e indiciamento: legitimidade e conformação constitucional. Belo Horizonte: Editora D’Plácido, 2017. p. 24.

${ }^{68}$ MARCÃO, Renato. Curso de processo penal. 4. ed. São Paulo: Saraiva Educação, 2018. p. 65.
} 
Estado de Direito sem um processo que atue dentro dos modelos legais tipificados. ${ }^{69}$ No mesmo norte:

"Trata-se de uma cláusula inserida em nosso ordenamento jurídico como guarda-chuva, sob a qual se abrigam direitos, garantias, princípios, regras, valores, deveres e proibições, catalogadas e implícitas, abarcando a esfera interna e internacional (art. $5, \S 2^{\circ}$, da CF)., ${ }^{70}$

Sucedâneo lógico do devido processo legal é o direito ao contraditório e à ampla defesa, que também possuem assento constitucional no rol de direitos fundamentais. ${ }^{71}$

Observa-se, pois, que carece de qualquer constitucionalidade um processo criminal fruto da inobservância do devido processo legal, com todos seus princípios, garantias e regras inerentes.

O que ocorre, contudo, com relação ao inquérito policial, que tecnicamente é um procedimento administrativo, e não um processo administrativo ou judicial?

Grande parte da doutrina nacional advoga no sentido de que por se tratar de um procedimento, e não um processo - seja ele administrativo ou judicial - não haveria a incidência de todos os princípios, garantias e regras inerentes ao devido processo legal. ${ }^{72}$

Deste modo, realiza-se uma interpretação restritiva, de modo a fundamentar a posição de que um mero procedimento administrativo não faria jus ao contraditório e à ampla defesa. ${ }^{73}$

Contudo, não é forçoso concluir que de um procedimento administrativo como o inquérito policial advém diversas medidas de caráter restritivas ao sujeito investigado, seja de constrição patrimonial, seja de cerceamento da liberdade ambulatorial.

\footnotetext{
${ }^{69}$ Ibid. p. 65/66.

${ }^{70}$ GIACOMOLLI, Nereu José. Op. cit., p. 99. Também sobre a importância do devido processo legal, Estêvão Luís afirma que "pode-se atribuir ao devido processo legal a natureza de um princípio fundamental, nele repousando todos os demais princípios processuais." JORGE, Estêvão Luís Lemos. Op. cit., p. 28.

${ }^{71}$ LV - aos litigantes, em processo judicial ou administrativo, e aos acusados em geral são assegurados o contraditório e ampla defesa, com os meios e recursos a ela inerentes;

${ }^{72}$ LOPES JUNIOR, Aury. Direito Processual Penal. 12. ed. São Paulo: Saraiva, 2015. p. $170 / 172$.

${ }^{73}$ Ibid. p. 170/172.
} 
Consequência lógica desta assertiva é a necessidade de observância no procedimento administrativo do devido processo legal. De forma inovadora, ainda que sobre tema diverso, importante o entendimento sumulado no $\mathrm{STJ}^{74}$ sobre a necessidade de observância do direito de defesa por advogado ou defensor em procedimento administrativo que apure a prática de falta disciplinar no âmbito da execução penal.

Não assemelha muita diferença entre $o$ procedimento administrativo para apuração de falta disciplinar e o procedimento administrativo pré-processual, visto que o que temos aqui é uma ameaça a liberdade de ir e vir. Logo, é necessária a devida observância da ampla defesa e contraditório na fase preliminar de investigação, de modo a fomentar o cláusula do due process of law.

Portanto, aparenta ser a melhor posição a do eminente professor Aury Lopes, ao militar no sentido da aplicação do contraditório e da ampla defesa mesmo em sede da investigação preliminar de modo a trazer maior aproximação da investigação preliminar com os ditames constitucionais $^{75}$ e de observar o princípio fundamental do devido processo legal em todas as esferas do processo penal, incluindo sua fase preliminar.

Corroborando o entendimento da incidência do devido processo legal na investigação preliminar, muito elucidativa a lição de Leonardo Marcondes Machado. Segundo o dito autor, há um movimento que deve "nos conduzir à observância, cada vez maior, da cláusula do due process of law na etapa da investigação preliminar, com irrestrito zelo pelos direitos e garantias fundamentais. ",76

\footnotetext{
${ }^{74}$ Súmula 533 STJ: Para o reconhecimento da prática de falta disciplinar no âmbito da execução penal, é imprescindivel a instauração de procedimento administrativo pelo diretor do estabelecimento prisional, assegurado o direito de defesa, a ser realizado por advogado constituído ou defensor público nomeado.

${ }^{75}$ LOPES JUNIOR, Aury. Direito Processual Penal. 12. ed. São Paulo: Saraiva, 2015. p. $170 / 173$.

${ }^{76}$ MACHADO, Leonardo Marcondes. Investigação Preliminar: por uma política de redução de dor. In: KHALED JR., Salah. H. (Coord.). Sistema penal e poder punitivo: estudos em homenagem ao prof. Aury Lopes Jr. Florianópolis: Empório do Direito, 2015. p. 337. Também segundo o referido autor, o devido procedimento legal esculpido no artigo $5^{\circ}$, LIV da CRFB
} 


\subsection{IMPARCIALIDADE DO JUIZ}

A importância de ser julgado por um juiz imparcial é tema que há muito tempo a doutrina se debruça devido à sua complexidade e à sua imprescindibilidade para um julgamento justo e de acordo com os ditames legais.

Rubens Casara assim define o conceito:

"Imparcialidade é sinônimo de alheabilidade, ou seja, os juízes não podem ter interesse pessoal em relação ao resultado do processo, nem atuar para retirar proveito político, midiático, financeiro ou social da causa posta em julgamento. Mais do que isso: todo julgador deve ter contato com o processo em uma situação de não-saber, sem ter convicções ou certezas acerca dos fatos atribuídos ao acusado." 77

Muito se dizia que o juiz era imparcial quando fazia a aplicação formal da subsunção do fato à norma, sem levar em conta todos os préconceitos, pré-juízos e valores que o Estado-Juiz possuía como membro de uma sociedade organizada.

Tal conceituação é contudo demasiadamente ingênua e inverídica. Ora, o juiz - assim como qualquer cidadão - é uma pessoa que vive em uma sociedade complexa, muito diversificada e profundamente desigual.

Por isso, mister se faz diferenciar os conceitos de neutralidade e parcialidade, abandonando assim a ideia de que o juiz é um ser "neutro"7879. Outrossim, Rubens Casara afirma:

vincula o inquérito policial em um Estado de Direito. MACHADO, Leonardo Marcondes. O inquérito policial goza de contraditório (mitigado) e defesa (limitada). Disponível em $<$ https://www.conjur.com.br/2018-set-04/academia-policia-inquerito-policial-goza-contraditoriomitigado-defesa-limitada>. Acesso em 16 abr. 2019.

${ }^{77}$ CASARA, Rubens R. R.. Vamos levar a imparcialidade judicial a sério? Disponível em $<$ http://www.justificando.com/2019/02/27/vamos-levar-a-imparcialidade-judicial-aserio/?fbclid=IwAR3zIwLsDx9aC5ALurF1JuAyBImW_iPGyM39Q_Ov89C5R9o8ZKgXwsf1X8>. Acesso em 28 mar. 2019.

${ }^{78}$ Nereu José Giacomolli também traz a equidade como um conceito necessário de ser afastado da imparcialidade. Isso porque "Ao aproximar-se a imparcialidade do juiz de suas qualidades, confundiu-se imparcialidade com neutralidade e com a equidade, vislumbrando-se um horizonte intangível, ilusório e ideal.” GIACOMOLLI, Nereu José. Op. cit., p. 277.

${ }^{79}$ Cesare Beccaria já esboçava sobre o tema nos idos do século XVIII: "cada homem tem o seu ponto de vista; o mesmo homem, em épocas diferentes tem pontos de vista diferentes (...) Vemos, pois, a sorte de um cidadão mudar muitas vezes em sua passagem por diversos tribunais, e a vida dos miseráveis ser a vítima dos falsos raciocínios ou das variações ocasionais de humor de 
"Neutralidade, por definição, é a ausência de valores. O homem, e o juiz não é exceção (deve-se abandonar o mito do "juiz quase-divino"), é formado por valores que se agregam à personalidade durante a caminhada histórica de cada um. Há juízes reacionários e juízes progressistas, juízes que são racistas e sexistas e outros que respeitam a alteridade." ${ }^{80}$

Noutro giro, para Aury Lopes, a parcialidade significa "um estado subjetivo, emocional, um estado anímico do julgador. ",81

Francesco Carnelutti pontua que não há, em verdade, uma imparcialidade pura, pois a "justiça humana é uma justiça essencialmente parcial, porque devido à limitação do ser humano, só se resolve parcialmente. ",82

Uma vez que o juiz encontra-se previamente inclinado à tese de alguma das partes, a imparcialidade dele se mostra vilipendiada e por conseguinte o processo, formalmente válido, se mostra uma verdadeira farsa processual.

Não à toa, Geraldo Prado sacramenta:

"o devido processo legal só constitui, de fato, mecanismo civilizado de resolução de causas se o resultado não puder ser determinado antecipadamente, isto é, só há processo penal real se no início do procedimento ambas as teses de acusação e de resistência - puderem ser apresentadas em condições de convencer o juiz." 83

À vista disso, o legislador tentou disciplinar as hipóteses de possível infringência da imparcialidade do juiz ${ }^{84}$, tendo disciplinado a matéria nos artigos 252, 253 e 254 do Código de Processo Penal, tratando sobre o impedimento, incompatibilidade e suspeição, nesta ordem. ${ }^{85}$

um juiz, o qual toma como interpretação legítima o vago resultado de toda uma série de noções confusas que se agitam em sua mente." BECCARIA, Cesare. Dos delitos e das penas. Tradução de Lucia Guidicini e Alessandro Berti Contessa. São Paulo: Martins Fontes, 1991. p. 49.

${ }^{80}$ CASARA, Rubens R. R.. Op. cit.

${ }^{81}$ LOPES JUNIOR, Aury. Direito Processual Penal: e sua conformidade constitucional. 7. ed. Rio de Janeiro: Lumen Juris, 2011. p. 129.

${ }^{82}$ CARNELUTTI, Francesco. As Misérias do Processo Penal. Campinas, SP: Servanda Editora, 2016. p. 51.

${ }^{83}$ PRADO, Geraldo. Op. cit., p. 109.

${ }^{84}$ BADARÓ, Gustavo Henrique Righi Ivahy. Op. cit., p. 48.

${ }^{85}$ Sobre as causas de impedimento e suspeição, Geraldo Prado assevera que "há os casos de impedimento, pelos quais se objetiva excluir o juiz que possa ter interesse no resultado da causa; e existem as hipóteses de suspeição, normalmente voltadas a permitir a substituição do juiz interessado nas partes”. PRADO, Geraldo. Op. cit., p. 109. 
Também há casos em que o juiz era originalmente imparcial, contudo com seu atuar na investigação ou no processo, sua imparcialidade acaba cedendo e levando à tona a parcialidade, pois a imparcialidade do órgão julgador "é indispensável, do início da relação processual á sua decisão, eis que o fato gerador da parcialidade pode ser superveniente à instauração da relação processual. ",6

Isso ocorre nas demandas em que o juiz perde a sua parcialidade, quando por exemplo toma a posição de uma verdadeira parte no processo, atuando na produção de provas ex officio e deliberando sobre a melhor estratégia processual a ser adotada tanto para condenar quanto para absolver o acusado, atuando como verdadeira parte ${ }^{87}$ do processo.

Sobre os poderes instrutórios do juiz e sua relação com a quebra da imparcialidade, Aury Lopes indaga:

“A gestão/iniciativa probatória nas mãos do juiz conduz à figura do juiz-ator (e não espectador), núcleo do sistema inquisitório. Logo, destrói-se a estrutura dialética do processo penal, o contraditório, a igualdade de tratamento e oportunidades e, por derradeiro, a imparcialidade - o princípio supremo do processo." ${ }^{88}$

Continua o ilustre autor afirmando que a posição ativa do julgador se demonstra em duas facetas: "poderes investigatórios exercidos na investigação preliminar (fase pré-processual); poderes instrutórios, exercidos no processo. " 89

De fato muitos dispositivos do atual diploma processual penal permitem ao juiz poderes para atuação sem provocação, o que demonstra incompatibilidade das ditas normas com a imparcialidade que se espera do Estado-Juiz.

\footnotetext{
${ }^{86}$ CASARA, Rubens R. R. Mitologia processual penal. São Paulo: Saraiva, 2015. p. 146.

${ }^{87}$ A respeito do tema do juiz ser ou não uma "parte" no processo, muito interessante a análise de Francesco Carnelutti, para quem "Quando se diz que as partes estão perante o juiz para serem julgadas, já se subentende que o juiz não é uma delas. De fato, os juristas dizem que o juiz está super partes, isto é, ele está acima e as partes e o acusado abaixo (...) Entretanto, o juiz também é um homem e, nessa condição, ele também é uma parte. Eis ai a contradição que é debatida sobre o conceito de o juiz ser parte e, ao mesmo tempo, não ser. Ser um homem com deveres sobre-humanos, eis ai o seu drama" CARNELUTTI, Francesco. Op. cit., p. 47.

${ }^{88}$ LOPES JUNIOR, Aury. Direito Processual Penal: e sua conformidade constitucional. 7. ed. Rio de Janeiro: Lumen Juris, 2011. p. 129.

${ }^{89}$ Ibid. p. 129/130.
} 
$\mathrm{Na}$ fase pré-processual, os permissivos do codex processual penal esculpidos nos artigos $5^{\circ}$, II $^{90} ; 28^{91} ; 127^{92} ; 156^{93} ; 242^{94}$, são exemplos claros de poderes investigatórios do juiz, incompatíveis com a sua imparcialidade e com o sistema acusatório. ${ }^{95}$

Sem dúvidas, dos dispositivos supramencionados, a possibilidade de produção de provas ex officio pelo juiz, nos moldes do artigo 156 do CPP, é fruto de muitas críticas e gera maior descontentamento por parte da melhor doutrina, posto que:

"É do Estado-acusação o encargo de provar a responsabilidade criminal do acusado e a dimensão da sanção. No momento em que o julgador, na dúvida, determina a realização de provas, está retirando a sua toga de terceiro e vestindo a da acusação, sepultando o in dubio pro reo e a prestação da tutela jurisdicional criminal efetiva, com a observância do devido processo penal, pela contaminação da parcialidade. Atribuir ao julgador os poderes probatórios na condição de destinatário da prova? (...) Podemos falar em juiz ou em julgamento imparcial, nesses casos?",96

De todo o exposto, pode-se concluir que para garantir a imparcialidade do juiz, alguns artigos do Código de Processo Penal

\footnotetext{
${ }^{90}$ Art. $5^{\circ}$ Nos crimes de ação pública o inquérito policial será iniciado: II - mediante requisição da autoridade judiciária ou do Ministério Público, ou a requerimento do ofendido ou de quem tiver qualidade para representá-lo.

${ }^{91}$ Art. 28. Se o órgão do Ministério Público, ao invés de apresentar a denúncia, requerer o arquivamento do inquérito policial ou de quaisquer peças de informação, o juiz, no caso de considerar improcedentes as razões invocadas, fará remessa do inquérito ou peças de informação ao procurador-geral, e este oferecerá a denúncia, designará outro órgão do Ministério Público para oferecê-la, ou insistirá no pedido de arquivamento, ao qual só então estará o juiz obrigado a atender.

${ }^{92}$ Art. 127. O juiz, de ofício, a requerimento do Ministério Público ou do ofendido, ou mediante representação da autoridade policial, poderá ordenar o sequestro, em qualquer fase do processo ou ainda antes de oferecida a denúncia ou queixa.

${ }^{93}$ Art. 156. A prova da alegação incumbirá a quem a fizer, sendo, porém, facultado ao juiz de oficio: I - ordenar, mesmo antes de iniciada a ação penal, a produção antecipada de provas consideradas urgentes e relevantes, observando a necessidade, adequação e proporcionalidade da medida;

${ }^{94}$ Art. 242. A busca poderá ser determinada de ofício ou a requerimento de qualquer das partes.

${ }^{95}$ Também é possível observar os poderes investigatórios no regimento interno do STJ e STF, conforme dicção do artigo 58 RISTJ e artigo 43 do RISTF, respectivamente: Art. 58. Ocorrendo infração à lei penal na sede ou dependências do Tribunal, o Presidente instaurará inquérito, se envolver autoridade ou pessoa sujeita à sua jurisdição, ou delegará esta atribuição a outro Ministro. $\S 1^{\circ}$ Nos demais casos, o Presidente poderá proceder na forma deste artigo ou requisitar a instauração de inquérito à autoridade competente.; Art. 43. Ocorrendo infração à lei penal na sede ou dependência do Tribunal, o Presidente instaurará inquérito, se envolver autoridade ou pessoa sujeita à sua jurisdição, ou delegará esta atribuição a outro Ministro. $\S 1^{\circ}$ Nos demais casos, o Presidente poderá proceder na forma deste artigo ou requisitar a instauração de inquérito à autoridade competente.

${ }^{96}$ GIACOMOLLI, Nereu José. Op. cit., p. 284/285.
} 
devem ser revistos para que haja uma atuação do Estado-Juiz em conformidade com a constituição e com o sistema acusatório, de modo a tornar o exercício da jurisdição mais próximo dos preceitos necessários para a implementação de um efetivo Estado Democrático de Direito.

\subsubsection{IMPARCIALIDADE SUBJETIVA}

Apesar da imparcialidade ser um atributo de cunho subjetivo, a doutrina e a jurisprudência, notadamente no caso Piersack vs. Bélgica, julgada pelo Tribunal Europeu de Direitos Humanos (TEDH), distinguiram o conceito da imparcialidade em objetiva e subjetiva, para melhor compreensão do instituto ${ }^{97}$. Veja-se, pois, o que foi firmado no julgamento do TEDH em 01/10/1982:

"Si la imparcialidad se define ordinariamente por la ausencia de prejuicios o parcialidades, su existencia puede ser apreciada, especialmente conforme al artículo 6.1 del Convenio, de diversas maneras. Se puede distinguir así entre un aspecto subjetivo, que trata de averiguar la convicción personal de un juez determinado en un caso concreto, y un aspecto objetivo, que se refiere a si éste ofrece las garantías suficientes para excluir cualquier duda razonable al respecto". ${ }^{9}$

Assim sendo, entende-se que a imparcialidade subjetiva faz menção à percepção íntima do juiz, que toma ciência de determinados assuntos e, outrossim, da sua falta de pré-juízos. ${ }^{99}$

Destrinchando o conceito, Giacomolli pontua que em uma aproximação subjetiva:

“a imparcialidade identifica a inexistência de prejuízos (pré-juízos), de preconceitos inautênticos ou indevidamente adquiridos que possam viciar o julgamento, traduzindo-se na inexistência de uma convicção pessoal prévia acerca do objeto do julgamento, de uma opinião sobre o caso penal, ou sobre os sujeitos e partes envolvidos, um tomar partido antecipado sobre determinado problema criminal, ou um aderir às razões de uma das partes antes do momento

\footnotetext{
${ }^{97}$ BADARÓ, Gustavo Henrique Righi Ivahy. Op. cit., p. 49.

${ }^{98}$ ESTRASBURGO, Sentencia Del Tribunal Europeo De Derechos Humanos De. Caso Piersack $\begin{array}{llllll}\text { Contra } & \text { Bélgica } & 1 & \text { Octubre } & 1982 . & \text { Disponível }\end{array}$ $<$ http://www.cienciaspenales.net/files/2016/10/6caso-piersack-contra-belgica-derecho-a-unproceso-independiente-e-imparcial.pdf $>$. Acesso em 01 abr. 2019.

${ }^{99}$ LOPES JUNIOR, Aury. Direito Processual Penal: e sua conformidade constitucional. 7. ed. Rio de Janeiro: Lumen Juris, 2011. p. 133.
} 
processual estabelecido. Em suma, ter interesse pessoal no caso. Assim, presume-se a imparcialidade subjetiva do julgador."

Contudo, não basta apenas que o juiz seja subjetivamente imparcial. Mister que toda a sociedade acredite que o julgamento tenha sido realizada por um juiz imparcial. Caso o julgamento incorra em dúvidas à sociedade para com a imparcialidade do julgador, a decisão terá tanto descrédito quanto uma decisão proferida por um juiz intimamente comprometido com uma das partes. É sobre essa questão que recai a teoria da aparência geral da imparcialidade, uma vez que "justice must not only be done; it must also be seen to be done". ${ }^{101}$

\subsubsection{IMPARCIALIDADE OBJETIVA}

Na prática forense, os casos de violação da imparcialidade objetiva são mais comumente observadas do que os casos de violação da imparcialidade subjetiva. $^{102}$

A imparcialidade objetiva se relaciona não com a relação do juiz com as partes processuais, e sim da relação do juiz com o objeto do processo a ser julgado. ${ }^{103}$

Giacomolli ressalta que, na imparcialidade objetiva, examina-se se há:

"demonstração fática objetiva de uma quebra razoável da imparcialidade (concreção objetiva), ou seja, se os fatos possuem entidade suficiente para formar um juízo de suspeita acerca da imparcialidade do julgador; se a dúvida foi objetivamente justificada; se os temores da parte acerca da falta de imparcialidade foram objetivamente justificados." ${ }^{104}$

E conclui o autor que não significa, necessariamente, que estará quebrada a imparcialidade do juiz caso já tenha previamente proferido

\footnotetext{
${ }^{100}$ GIACOMOLLI, Nereu José. Op. cit., p. 278.

${ }^{101}$ BADARÓ, Gustavo Henrique Righi Ivahy. Op. cit., p. 51.

${ }^{102}$ Ibid. p. 49.

${ }^{103}$ LOPES JUNIOR, Aury. Direito Processual Penal: e sua conformidade constitucional. 7. ed. Rio de Janeiro: Lumen Juris, 2011. p. 133.

${ }^{104}$ GIACOMOLLI, Nereu José. Op. cit., p. 279.
} 
decisões na causa, devendo ser observada a parcialidade in casu, ou seja, é necessário analisar o conteúdo das decisões proferidas, e não tão somente o fato de o juiz as ter proferido. ${ }^{105}$

Contudo, o TEDH decidiu não só no caso Piersack vs. Bélgica como também no caso De Cubber vs. Bélgica ${ }^{106}$ que:

"a aparência de imparcialidade era comprometida nos casos em que havia a intervenção prévia do julgador na fase de investigação, proferindo decisões em que se realizasse uma antecipação quanto ao mérito da causa. Em tais situações, o jurisdicionado e, principalmente, o acusado, poderia suspeitar legitimamente de que não seria julgado por um juiz ou tribunal imparcial."

Urge, portanto, como consequência lógica, que a imparcialidade objetiva resta afrontada quando o juiz participa da investigação preliminar, seja adentrando ao mérito da causa ao resolver questões que clamam por cláusula de reserva jurisdicional, seja tomando verdadeiro impulso na produção de provas, confundindo-se com a figura do EstadoAcusação.

Nesse norte, Giacomolli destaca que além das hipóteses previstas em lei - leia-se de impedimento, suspeição e incompatibilidade - há outras maneiras que o juiz pode estar contaminado e com sua imparcialidade maculada:

"É o que ocorre quando o juiz mantém contato com os elementos testemunhais colhidos na fase de investigação, utilizando-os na inquirição e/ou valoração dos prestados na fase do contraditório judicial. Nessa perspectiva, a atuação no processo do mesmo magistrado que decretou medidas restritivas de direitos na fase pré-processual poderá gerar dúvida acerca de sua imparcialidade, por ter

\footnotetext{
${ }^{105}$ Ibid. p. 279.

${ }^{106}$ In conclusion, the impartiality of the Oudenaarde court was capable of appearing to the applicant to be open to doubt. Although the Court itself has no reason to doubt the impartiality of the member of the judiciary who had conducted the preliminary investigation (see paragraph 25 above), it recognises, having regard to the various factors discussed above, that his presence on the bench provided grounds for some legitimate misgivings on the applicant's part. Without underestimating the force of the Government's arguments and without adopting a subjective approach (see paragraphs 25 and 28 above), the Court recalls that a restrictive interpretation of Article 6 para. 1 (art. 6-1) - notably in regard to observance of the fundamental principle of the impartiality of the courts - would not be consonant with the object and purpose of the provision, bearing in mind the prominent place which the right to a fair trial holds in a democratic society within the meaning of the Convention. RIGHTS, Cour Européenne Des Droits De L'homme European Court Of Human. Case Of De Cubber V. Belgium (Application No. 9186/80) Judgment Strasbourg $26 \quad$ October $1984 . \quad$ Disponível em $<$ http://cambodia.ohchr.org/sites/default/files/echrsource/de\%20Cubber\%20v.\%20Belgium\%20[ 26\%20Oct\%201984]\%20[EN].pdf>. Acesso em 01 abr. 2019.

${ }^{107}$ BADARÓ, Gustavo Henrique Righi Ivahy. Op. cit., p. 50.
} 
examinado a situação fática e jurídica e produzido algum juízo, ainda que provisório, acerca da culpabilidade, fazendo-se mister averiguar o conteúdo das decisões para estabelecer a existência ou não de um juízo prévio."108

A partir dos conceitos delineados acima, realizar-se-á um estudo aprofundado sobre o atual papel do juiz na investigação preliminar, para correta compreensão das possíveis mudanças advindas pela inserção no ordenamento jurídico da figura do juiz de garantias.

${ }^{108}$ GIACOMOLLI, Nereu José. Op. cit., p. 284. 


\section{CAPÍTULO 3. A FIGURA DO JUIZ DE GARANTIAS}

\subsection{A ATUAL FUNÇÃO DO JUIZ NA INVESTIGAÇÃO PRELIMINAR}

A investigação preliminar é uma fase administrativa e preparatória do processo penal, que serve tanto para a instrumentalização de um futuro processo, bem como para a garantia do investigado contra processos levianos e infundados. ${ }^{109}$

Nas espécies de investigação preliminar - aqui destacam-se o IP e o $\mathrm{PIC}^{110}$ - o juiz possui, em tese, a função de garantidor dos direitos do investigado, se manifestando somente para decidir incidentes que visem restringir os direitos do investigado. ${ }^{111}$

Nesse sentido, Fauzi Hassan Choukr leciona:

“A visão garantidora coloca o magistrado na posição fundamental de salvaguarda dos direitos do investigado ainda na fase preparatória (onde justamente as garantias constitucionais não aparecem com nitidez), dando-se tal proteção através da jurisdicionalização dos incidentes investigativos que necessitem a legítima violação de direitos constitucionalmente estabelecidos para a apuração dos fatos."112

O que tem-se portanto é a figura de um juiz inerte, que somente atua ativamente para preservação dos direitos fundamentais do investigado, ao contrário da figura da polícia judiciária e do Ministério Público, que atuam ativamente na investigação do possível injusto penal.

A atuação positiva do juiz em atos de investigação violam explicitamente o sistema acusatório pois, segundo Elmir Duclerc, o juiz "pode ser chamado a atuar no inquérito policial, mas nunca com funções

\footnotetext{
${ }^{109}$ LOPES JUNIOR, Aury. Sistemas de investigação preliminar no processo penal. 4. ed. Rio de Janeiro: Lumen Juris, 2006. p. 41/50.

110 "o Ministério Público não só está legalmente autorizado a acompanhar ativamente a atividade policial no curso do inquérito, como também a investigar e a realizar sua própria investigação preliminar, vista como um procedimento administrativo pré-processual." Ibid. p. 157.

${ }^{111}$ Dentre esses incidentes, pode-se destacar o mandado de busca e apreensão, interceptação telefônica, infiltração de agentes e etc.

${ }^{112}$ CHOUKR, Fauzi Hassan. Brasil. In: MAIER, Julio B. J.; AMBOS, Kai; WOISCHNIK, Jan (Orgs.). Las reformas procesales penales en América Latina. Buenos Aires: Ad-Hoc, 2000. p 147.
} 
de investigação, pois isso violaria flagrantemente o sistema acusatório." "113

Ocorre que, conforme já consignado no subcapítulo 2.2, inúmeros dispositivos do diploma processual penal permitem essa atuação imprópria do juiz, ao arrepio da Constituição Federal.

Mais preocupante é que esse juiz que atuou positivamente na investigação preliminar estará prevento para o julgamento da causa, conforme vaticina o artigo 83 do $\mathrm{CPP}^{114}$, o que certamente fará com que leve sua contaminação até esgotada a sua jurisdição.

Com críticas à prevenção como critério definidor da competência, Aury Lopes destaca:

“A nosso juízo, deveria ser uma causa de exclusão, pois, determinar que o mesmo juiz que homologou uma prisão em flagrante ou decretou a prisão temporária ou preventiva no curso do inquérito seja o que irá receber e julgar a causa não é o melhor critério. A prevenção pode fulminar a principal garantia das partes no processo penal: o direito a um juiz imparcial." 115

Se por um lado a prevenção é defendida pela lógica de que o juiz que teve anterior contato com a causa conheceria melhor a situação e estaria mais apto a julgar, não se pode, contudo, deixar de lado que se o juiz “já decretou uma medida cautelar anterior ao processo, já se pronunciou sobre os mesmos elementos (...) já antecipou a sua decisão nesse sentido, e por isso deve ser considerado impedido."116

Imprescindível se torna o afastamento da figura desse juiz que atuou na investigação preliminar da ação penal, bem como a desautorização de sua atuação positiva na fase preliminar, para garantia de um julgamento imparcial.

\footnotetext{
${ }^{113}$ DUCLERC, Elmir. Curso Básico de Direito Processual Penal. 2. ed. vol. I. Rio de Janeiro: Lumen Juris, 2006. p. 164.

${ }^{114}$ Art. 83. Verificar-se-á a competência por prevenção toda vez que, concorrendo dois ou mais juizes igualmente competentes ou com jurisdição cumulativa, um deles tiver antecedido aos outros na prática de algum ato do processo ou de medida a este relativa, ainda que anterior ao oferecimento da denúncia ou da queixa.

115 LOPES JUNIOR, Aury. Sistemas de investigação preliminar no processo penal. 4. ed. Rio de Janeiro: Lumen Juris, 2006. p. 174.

${ }^{116}$ DUCLERC, Elmir. Op. cit., p. 68. Nessa mesma toada, “a atuação no processo do mesmo magistrado que decretou medidas restritivas de direitos na fase pré-processual poderá gerar dúvida acerca de sua imparcialidade (...).” GIACOMOLLI, Nereu José. Op. cit., p. 284.
} 
Suponha-se a seguinte hipótese: o juiz atua na fase de investigação, decreta a prisão temporária, a prorroga, após decreta a prisão preventiva, decreta a indisponibilidade de bens, a busca e apreensão e a produção de provas de ofício. Após, recebe a denúncia, indefere inúmeros pedidos de revogação de prisão preventiva, contudo, quando chega na fase de sentença, percebe que o acusado é inocente, ou que não há provas suficientes para condená-lo, observado o princípio do in dubio pro reo.

Nessa situação imaginária - porém não incomum no cotidiano forense - não é forçoso concluir que o magistrado, às vezes por orgulho, às vezes meramente por ego, não queira absolver o acusado e demonstrar que se equivocou durante todo o processo ao julgar todos os incidentes e ao tomar posição de verdadeiro acusador. ${ }^{117}$

Não é de se olvidar a importância da independência funcional dos juízes nas suas decisões. Contudo, o próprio Estado-Juiz entra em um dilema interno e acaba condenando a pessoa somente por provas indiciárias, realizando uma ginástica hermenêutica das provas produzidas em juízo sob o crivo do contraditório e da ampla defesa, considerando os elementos informativos constantes na investigação preliminar - na qual ele participou ativamente - como provas irrefutáveis da ocorrência de um injusto penal.

\section{Por isso, Fauzi Hassan Choukr assevera: \\ "é de ser considerado que não há distinção entre a figura do juiz que acompanha as investigações (p. ex. determinando a prisão preventiva do suspeito), verificar a admissibilidade da ação penal e venha a julgar esta mesma ação. Trata-se, evidentemente, de fatos de complicação para a aplicação substancial da imparcialidade, na medida em que sua formação de convencimento já está comprometida com o desenrolar dos fatos desde antes do início da ação penal propriamente dita."}

\footnotetext{
${ }^{117}$ Simone Schreiber traz uma importante ponderação sobre o tema, ao assinalar que: "se foi ele próprio (juiz) quem avaliou a pertinência e a legalidade das medidas probatórias realizadas na fase pré-processual, é bastante improvável que ele desqualifique a prova que foi produzida e mude de ideia quanto ao resultado que foi colhido". SCHREIBER, Simone. O juiz de garantias no projeto do código de processo penal. In: Boletim do IBCCRIM, São Paulo, ago. 2010, v. 18, n. 213, p. 02/03.

${ }^{118}$ CHOUKR, Fauzi Hassan. Brasil. In: MAIER, Julio B. J.; AMBOS, Kai; WOISCHNIK, Jan (Orgs.). Las reformas procesales penales en América Latina. Buenos Aires: Ad-Hoc, 2000. p. 141.
} 
Por isso a necessidade da criação da figura do juiz de garantias, para garantir a legalidade da investigação preliminar, vedar a atuação positiva na fase pré-processual e manter imparcialidade do juiz competente para o julgamento do mérito.

A importância devida de sua necessidade pode ser observada no seguinte excerto:

"A possibilidade da atuação de um juiz de garantias na fase preliminar do processo penal, diverso do que conduzirá o processo e julgará o imputado, oferece um espectro maior de diminuição de fatores de contaminação subjetiva, auxiliando na exclusão de dúvidas acerca da imparcialidade do julgador."119

É exatamente sobre essa figura que serão elaborados os próximos subcapítulos. Senão, veja-se.

\subsection{O PROJETO DE LEI No $8045 / 2010$}

O anteprojeto de reforma do Código de Processo Penal, de autoria do outrora Senador José Sarney, tramitou pelo Senado Federal sob o registro de PLS 156/2009, tendo sido aprovado na Sessão Extraordinária do dia 07/12/2010 e remetido para a Câmara dos Deputados, agora sob número de $\mathrm{PL} \mathrm{n}{ }^{\circ} 8045 / 2010 .{ }^{120}$

Eis a comissão de juristas responsáveis pela elaboração do anteprojeto de reforma do Código de Processo Penal: Hamilton Carvalhido (Coordenador); Eugênio Pacelli de Oliveira (Relator); Antonio Correa; Antonio Magalhães Gomes Filho; Fabiano Augusto Martins Silveira; Felix Valois Coelho Júnior; Jacinto Nelson de Miranda Coutinho; Sandro Torres Avelar; e Tito Souza do Amaral. ${ }^{121}$

\footnotetext{
${ }^{119}$ GIACOMOLLI, Nereu José. Op. cit., p. 284.

120 Informações disponíveis no site oficial do Senado Federal. Disponível em $<$ https://www25.senado.leg.br/web/atividade/materias/-/materia/90645>. Acesso em 05 abr. 2019.

${ }^{121}$ SENADO FEDERAL DO BRASIL. Anteprojeto de Reforma do Código de Processo Penal / Comissão de Juristas Responsável pela Elaboração de Anteprojeto de Reforma do Código de Processo Penal. - Brasília: Senado Federal, Subsecretaria de Edições Técnicas, 2009. Disponível em <http://www2.senado.leg.br/bdsf/bitstream/handle/id/182956/000182956.pdf?sequence=10 $>$. p. 05. Acesso em 05 abr. 2019.
} 
Do eminente grupo de juristas responsáveis pela comissão, adveio a exposição de motivos do novo $\mathrm{CPP}$, que merece transcrição pela maneira didática e elucidativa que trata a figura do juiz de garantias. In verbis:

"Para a consolidação de um modelo orientado pelo princípio acusatório, a instituição de um juiz de garantias, ou, na terminologia escolhida, de um juiz das garantias, era de rigor. Impende salientar que o anteprojeto não se limitou a estabelecer um juiz de inquéritos, mero gestor da tramitação de inquéritos policiais. Foi, no ponto, muito além. O juiz das garantias será o responsável pelo exercício das funções jurisdicionais alusivas à tutela imediata e direta das inviolabilidades pessoais. A proteção da intimidade, da privacidade e da honra, assentada no texto constitucional, exige cuidadoso exame acerca da necessidade de medida cautelar autorizativa do tangenciamento de tais direitos individuais. O deslocamento de um órgão da jurisdição com função exclusiva de execução dessa missão atende à duas estratégias bem definidas, a saber: a) a otimização da atuação jurisdicional criminal, inerente à especialização na matéria e ao gerenciamento do respectivo processo operacional; e b) manter o distanciamento do juiz do processo, responsável pela decisão de mérito, em relação aos elementos de conviç̧ão produzidos e dirigidos ao órgão da acusação.

No âmbito, ainda, da persecução penal na fase de investigação preliminar, o anteprojeto traz significativa alteração no que respeita à tramitação do inquérito policial. A regra do atual Código de Processo Penal não guarda qualquer pertinência com um modelo processual de perfil acusatório, como se deduz do sistema dos direitos fundamentais previstos na Constituição. A investigação não serve e não se dirige ao Judiciário; ao contrário, destina-se a fornecer elementos de convencimento, positivo ou negativo, ao órgão da acusação. Não há razão alguma para o controle judicial da investigação, a não ser quando houver risco às liberdades públicas, como ocorre na hipótese de réu preso. Neste caso, o curso da investigação será acompanhado pelo juiz das garantias, não como controle da qualidade ou do conteúdo da matéria a ser colhida, mas como fiscalização do respeito aos prazos legais previstos para a persecução penal. Atuação, como se vê, própria de um juiz das garantias."

O diploma em comento possui 756 artigos, sendo certo que a figura do juiz de garantias encontra-se disciplinada dentro do Livro I " $D A$ PERSECUÇÃO PENAL”, Título II “Da Investigação Criminal”, Capítulo II “Do Juiz das Garantias”, em seus artigos 14 a 17. Colacionam-se os artigos:

“Art. 14. O juiz das garantias é responsável pelo controle da legalidade da investigação criminal e pela salvaguarda dos direitos individuais cuja franquia tenha sido reservada à autorização prévia do Poder Judiciário, competindo-lhe especialmente:

I - receber a comunicação imediata da prisão, nos termos do inciso LXII do art.

$5^{\circ}$ da Constituição da República Federativa do Brasil;

${ }^{122}$ Ibid. p. 17. 
II - receber o auto da prisão em flagrante, para efeito do disposto no art. 555;

III - zelar pela observância dos direitos do preso, podendo determinar que este seja conduzido a sua presença;

IV - ser informado sobre a abertura de qualquer investigação criminal;

$\mathrm{V}$ - decidir sobre o pedido de prisão provisória ou outra medida cautelar;

VI - prorrogar a prisão provisória ou outra medida cautelar, bem como substituí-las ou revogá-las;

VII - decidir sobre o pedido de produção antecipada de provas consideradas urgentes e não repetíveis, assegurados o contraditório e a ampla defesa;

VIII - prorrogar o prazo de duração do inquérito, estando o investigado preso, em vista das razões apresentadas pelo delegado de polícia e observado o disposto no parágrafo único deste artigo;

IX - determinar o trancamento do inquérito policial quando não houver fundamento razoável para sua instauração ou prosseguimento;

$\mathrm{X}$ - requisitar documentos, laudos e informações ao delegado de polícia sobre o andamento da investigação;

$\mathrm{XI}$ - decidir sobre os pedidos de:

a) interceptação telefônica, do fluxo de comunicações em sistemas de informática e telemática ou de outras formas de comunicação;

b) quebra dos sigilos fiscal, bancário e telefônico;

c) busca e apreensão domiciliar;

d) acesso a informações sigilosas;

e) outros meios de obtenção da prova que restrinjam direitos fundamentais do investigado.

XII - julgar o habeas corpus impetrado antes do oferecimento da denúncia;

XIII - determinar a realização de exame médico de sanidade mental, nos termos do art. $452, \S 1^{\circ}$;

XIV - arquivar o inquérito policial;

$\mathrm{XV}$ - assegurar prontamente, quando se fizer necessário, o direito de que tratam os arts. 11 e 37 ;

XVI - deferir o pedido de admissão de assistente técnico para acompanhar a produção da perícia;

XVII - outras matérias inerentes às atribuições definidas no caput deste artigo.

Parágrafo único. Estando o investigado preso, o juiz das garantias poderá, mediante representação do delegado de polícia e ouvido o Ministério Público, prorrogar, uma única vez, a duração do inquérito por até 15 (quinze) dias, após o que, se ainda assim a investigação não for concluída, a prisão será imediatamente relaxada..

Art. 15. A competência do juiz das garantias abrange todas as infrações penais, exceto as de menor potencial ofensivo e cessa com a propositura da ação penal.

$\S 1^{\circ}$ Proposta a ação penal, as questões pendentes serão decididas pelo juiz do processo.

$\S 2^{\circ}$ As decisões proferidas pelo juiz das garantias não vinculam o juiz do processo, que, após o oferecimento da denúncia, poderá reexaminar a necessidade das medidas cautelares em curso.

$\S 3^{\circ}$ Os autos que compõem as matérias submetidas à apreciação do juiz das garantias serão apensados aos autos do processo.

Art. 16. O juiz que, na fase de investigação, praticar qualquer ato incluído nas competências do art. 14 ficará impedido de funcionar no processo, observado o disposto no art. 748. 
Art. 17. O juiz das garantias será designado conforme as normas de organização judiciária da União, dos Estados e do Distrito Federal."123124

Tendo como substrato a exposição de motivos do novo CPP, assim como todos os artigos do novo diploma que tratam sobre o tema, far-se-á a análise conceitual e doutrinária sobre o instituto, sempre levando em consideração sua aplicação prática a partir dos referidos artigos.

\subsection{OBJETIVOS DO JUIZ DE GARANTIAS}

Conforme delineado acima no artigo 15, caput, o juiz de garantias possui uma competência bem delimitada, durante toda a investigação preliminar até o oferecimento da denúncia.

Contudo, o instituto não visa de modo algum se aproximar da figura do juiz ou juizado de instrução observados na Espanha e França, onde o juiz preside a investigação preliminar, que funciona como verdadeira instrução processual, restando para um magistrado diverso apenas a prolação da sentença, visto que não teve contato com as provas. $^{125126}$

Também em nada se assemelha com as Varas de Inquérito presentes em algumas localidades, a exemplo das cidades de São Paulo SP e Belo Horizonte - MG. Isso porque:

\footnotetext{
${ }^{123}$ Após emendas ao texto original proposto no Senado Federal, houve a mudança da redação de alguns artigos, bem como a supressão ou adição de outros. Destarte, o PL nº 8045/2010 mostrase um pouco diferente do texto original do PLS 145/2009.

${ }^{124}$ CÂMARA DOS DEPUTADOS DO BRASIL. Código de Processo Penal. Disponível em $<$ https://www.camara.leg.br/proposicoesWeb/prop_mostrarintegra?codteor $=1638152 \&$ filename $=$ PL+8045/2010>. Acesso em 05 abr. 2019.

${ }^{125}$ JORGE, Estevão Luís Lemos. Op. cit., p. 89.

126 "países com longa tradição na adoção do sistema de instrução preliminar judicial - como França e Espanha - estão hoje em amplo debate e caminham no sentido de profundas reformas, pois um pensamento é unânime: o modelo de juiz instrutor está em crise. No mesmo sentido, países como Alemanha (1974), Itália (1988) e Portugal (1987 e 1995) romperam definitivamente com o sistema de juiz instrutor, por absoluta insatisfação." LOPES JUNIOR, Aury. Sistemas de investigação preliminar no processo penal. 4. ed. Rio de Janeiro: Lumen Juris, 2006. p. 287. Importante também a lição de Luiz Flávio Gomes, para quem "O juiz das garantias (projetado), de outro lado, não tem nada a ver com o juiz ou juizado de instrução (da Espanha e França, v. G.). O juiz das garantias não vai presidir o inquérito policial.” GOMES, Luiz Flávio. O juiz das garantias projetado pelo novo CPP. Disponível em $<$ https://professorlfg.jusbrasil.com.br/artigos/121917615/o-juiz-das-garantias-projetado-pelonovo-cpp >. Acesso em 08 abr. 2019.
} 
"os poderes instrutórios, o controle sobre a qualidade do inquérito policial, a determinação de medidas de ofício, tudo isto, está autorizado no atual modelo vigente em relação ao Magistrado que atua na fase de investigação, ainda que seja em localidade que possuam Varas de Inquérito, que são juízes destinados só aos inquéritos policiais." ${ }^{27128}$

\section{Luiz Flávio Gomes espanca quaisquer dúvidas sobre a diferença}

entre o juiz de garantias e o juiz de vara de inquérito, pois:

"O juiz das garantias, como se vê, não é o "juiz do inquérito", que terá tramitação normal, sem a interferência desse juiz, salvo para resguardar os direitos e garantias individuais. Ele será o responsável pelo exercício das funções jurisdicionais relacionadas com a tutela imediata e direta dessas garantias. Com isso, o que se conquista é o distanciamento do juiz do processo (do juiz que vai presidir o posterior processo criminal)."

O juiz de garantias possui, pois, uma atuação bem diferenciada dos dois institutos acima mencionados, já que está "a serviço de uma outra cultura e com outro propósito", 130

Indubitavelmente um de seus maiores propósitos é a efetiva implantação do sistema acusatório no ordenamento jurídico brasileiro, afastando o juiz da atividade probatória e, por conseguinte, protegendo a sua imparcialidade.

Tal ponderação encontra-se inclusive estampada no artigo $4^{\circ}$ do $\mathrm{PL}$ $8045 / 2010$, ao dispor que:

\footnotetext{
${ }^{127}$ OLIVEIRA, Daniel Kessler de. Por que precisamos do juiz de garantias?. Disponível em < https://canalcienciascriminais.com.br/juiz-garantias/>. Acesso em 08 abr. 2019.

${ }^{128}$ No próprio Relatório final da Comissão Temporária do Senado que examinou o PL 145/2009 referente ao novo CPP, ficou consignado a diferenciação do juiz de garantias e o juiz da vara de inquérito: "Todavia, é preciso ter claro que o juiz das garantias difere do juiz das varas de inquérito policial, hoje instituídas em algumas capitais, como São Paulo e Belo Horizonte. É que o juiz das garantias deve ser compreendido na estrutura do modelo acusatório que se quer adotar. Por conseguinte, o juiz das garantias não será o gerente do inquérito policial, pois não lhe cabe requisitar a abertura da investigação tampouco solicitar diligências à autoridade policial. Ele agirá mediante provocação, isto é, a sua participação ficará limitada aos casos em que a investigação atinja direitos fundamentais da pessoa investigada. O inquérito tramitará diretamente entre polícia e Ministério Público. Quando houver necessidade, referidos órgão dirigir-se-ão ao juiz das garantias. Hoje, diferentemente, tudo passa pelo juiz da vara de inquéritos policiais." SENADO FEDERAL. Parecer $\mathrm{n}^{\circ}$, de 2009. Da comissão temporária de estudo da reforma do código de processo penal, sobre o Projeto de Lei do Senado $\mathrm{n}^{\mathrm{o}} 156$, de 2009, que reforma o Código de Processo Penal, e proposições anexadas. Disponível em $<$ https://www.migalhas.com.br/arquivo_artigo/art20091201-01.pdf > . Acesso em 08 abr. 2019.

${ }^{129}$ GOMES, Luiz Flávio. O juiz das garantias projetado pelo novo CPP. Disponível em $<$ https://professorlfg.jusbrasil.com.br/artigos/121917615/o-juiz-das-garantias-projetado-pelonovo-cpp>. Acesso em 08 abr. 2019.

${ }^{130}$ OLIVEIRA, Daniel Kessler de. Op. cit.
} 
“Art. $4^{\circ} \mathrm{O}$ processo penal terá estrutura acusatória, nos limites definidos neste Código, vedada a iniciativa do juiz na fase de investigação e a substituição da atuação probatória do órgão de acusação." 131

Por isso, segundo André Machado Maya, na atuação do juiz de garantias:

"competiria o resguardo da legalidade da investigação criminal e da irrestrita observância dos direitos fundamentais do suspeito, dependendo da sua autorização a concretização de medidas cautelares reais e pessoais e a busca de provas que impliquem ou possam implicar supressão de direitos fundamentais." $" 132$

Feita a necessária diferenciação da figura do juiz de garantias para a figura do juiz de instrução e do juiz da vara de inquérito, serão analisados os objetivos de sua implementação, com enfoque na sua atuação na investigação preliminar e consequente otimização e especialização na matéria, bem como no afastamento do processo de conhecimento do juiz contaminado.

\subsubsection{A FUNÇÃO NA INVESTIGAÇÃO PRELIMINAR}

A função que se busca do juiz de garantias na investigação preliminar é aquela que melhor coaduna com o sistema acusatório e o respeito ao devido processo legal.

Com efeito, sua atuação encontra-se muito bem ilustrada no novel CPP, sendo o magistrado o responsável pelo "controle da legalidade da investigação criminal" e pela "salvaguarda dos direitos individuais cuja franquia tenha sido reservada à autorização prévia do Poder Judiciário. ${ }^{133}$

\footnotetext{
${ }^{131}$ CÂMARA DOS DEPUTAdOS DO BRASIL. Código de Processo Penal. Disponível em $<$ https://www.camara.leg.br/proposicoesWeb/prop_mostrarintegra?codteor $=1638152 \&$ filename $=$ PL+8045/2010>. Acesso em 08 abr. 2019.

${ }^{132}$ MAYA, André Machado. Imparcialidade e Processo Penal: da prevenção da competência ao juiz de garantias. Rio de Janeiro: Lumes Juris, 2011. p. 221.

${ }^{133}$ CÂMARA DOS DEPUTADOS DO BRASIL. Código de Processo Penal. Disponível em $<$ https://www.camara.leg.br/proposicoesWeb/prop_mostrarintegra?codteor=1638152\&filename $=$ PL $+8045 / 2010>$. Acesso em 15 abr. 2019.
} 
E não poderia ser diferente a sua função. Em qualquer ordenamento que se preze, o respeito aos ditames constitucionais deve ser observado cabalmente, sob pena de descrédito e descrença no Poder Judiciário.

Simone Schreiber ilustra que, no que tange ao juiz, sua função não "é a de coadjuvar a polícia ou o ministério público na apuração dos fatos ocorridos, mas sim de garantir os direitos das pessoas eventualmente atingidas pela investigação. "134

É exatamente esse o papel que o juiz de garantias visa trazer. Preleciona Danielle Souza que "O juiz garantidor, tal como propriamente concebido, não investiga; mantém-se afastado da investigação preliminar. "135 E continua a autora afirmando que cabe a ele a ingerência na matéria que afete ou limite direitos individuais, bem como de impugnações aos atos da polícia e do Ministério Público. ${ }^{136}$

A ele não cabem funções meramente administrativa-burocráticas de requisitar diligências ordinárias e de fiscalizar cumprimentos de prazos de investigações, e sim verdadeiras funções de um magistrado em um sistema acusatório: a função de garantidor. ${ }^{137}$

Isso porque sua atuação na fase pré-processual exige uma limitação muito bem desenhada, não como investigador ou instrutor, mas como garante da legalidade dos atos e protetor dos direitos fundamentais do sujeito investigado. ${ }^{138}$

Em análise aprofundada sobre o tema, Mauro Fonseca Andrade disseca as funções do juiz de garantias na investigação preliminar:

\footnotetext{
${ }^{134}$ SCHREIBER, Simone. O juiz de garantias no projeto do código de processo penal. In: Boletim do IBCCRIM, São Paulo, ago. 2010, v. 18, n. 213, p. 02/03.

${ }^{135}$ CAVALCANTI, Danielle Souza de Andrade e Silva. O Juiz de Garantias na Investigação Preliminar Criminal. In: BASTOS, Marcelo Lessa; AMORIM, Pierre Souto Maior Coutinho de (Orgs.). Tributo a Afrânio Silva Jardim: escritos e pareceres. Rio de Janeiro: Lumen Juris, 2011. p. 39.

${ }^{136}$ Ibid. p. 43

${ }^{137}$ Ibid. p. 37.

${ }^{138}$ LOPES JÚNIOR, Aury; RITTER, Ruiz. A Imprescindibilidade do Juiz das Garantias para uma Jurisdição Penal Imparcial: Reflexões a Partir da Teoria da Dissonância Cognitiva. In: Revista Magister de Direito Penal e Processual Penal. Porto Alegre: Magister, ago./set. 2016, v. 73. p. 14.
} 
"a atividade de "controle da legalidade da investigação criminal", tal como referido pelo caput do artigo 14 do projeto, remete a uma complementação da atividade de garante dos direitos fundamentais, também confiada ao juiz das garantias. Não por outro motivo, diz-se que "o controle é uma forma de garantia", e, por sua vez, "a garantia se expressa através do controle."”,139

Portanto, o que se revela é a opção por uma função inerte do juiz de garantias, nos moldes do artigo $4^{\circ}$ do PL $8045 / 2010^{140}$, clamado para se manifestar apenas quando demandar a necessária cláusula de reserva de jurisdição, e sempre no intento de garantir o respeito e observância dos direitos fundamentais do sujeito investigado, não reproduzindo os permissivo legais - já exaustivamente trazidos à baila neste trabalho sobre a possibilidade de atuação ex officio do magistrado na fase de investigação preliminar.

Logo, não haverá mais possibilidade da atuação estapafúrdia e esdrúxula do Estado-Juiz, se imiscuindo em atividades exclusivamente investigatórias, como é observado hoje em dia na vigência de nosso Código de Processo Penal.

Caso ocorra uma atuação positiva do juiz de garantias em desconformidade com o sistema acusatório, haverá a nulidade absoluta dos atos, por violação ao artigo $4^{\mathrm{o}}$ do novo diploma. ${ }^{141}$

Além de garantir a legalidade da investigação preliminar, o juiz de garantias possui função de salvaguardar os direitos do sujeito incluído no polo passivo dessa fase preliminar.

Não à toa, o próprio nome desse novo modelo de juiz já demonstra explicitamente a importância que foi dada pelo novel diploma a essa função primordial para a investigação preliminar. ${ }^{142}$

Tal função não é tão inovadora em nosso ordenamento jurídico, visto que, pela cláusula de reserva de jurisdição, inúmeras questões que

\footnotetext{
${ }^{139}$ ANDRADE, Mauro Fonseca. Juiz das Garantias. Curitiba: Juruá, 2011. p. 81.

${ }^{140}$ Ibid. p. 90/91.

${ }^{141}$ LUZ, Denise; SILVEIRA, Leon Murelli. A Angústia de Decidir e o Juiz das Garantias no Projeto de Reforma do CPP: Uma importante Contribuição da Psicanálise para o Direito. In: Revista Magister de Direito Penal e Processual Penal. Porto Alegre: Magister, dez.jjan. 2013, v. 51. p. 19

${ }^{142}$ ANDRADE, Mauro Fonseca. Op. cit., p. 79.
} 
envolvem a violação a direitos fundamentais do investigado, como por exemplo a prisão provisória ou o sequestro de bens, só podem ser realizadas mediante autorização judicial.

Impende salientar que na mesma toada que o juiz de garantias deve tutelar os direitos do investigado, há de se proteger também a defesa técnica, notadamente em casos de obstrução de acesso aos autos, ou de vedação, por parte dos órgãos de persecução, da atuação positiva da defesa técnica nessa fase pré-processual.

Como bem salienta Aury Lopes e Ruiz Ritter:

"a intervenção do órgão jurisdicional deve ser contingente e excepcional. Isso porque o inquérito policial pode iniciar, desenvolver-se e ser concluído sem a intervenção do juiz, sendo chamado quando a excepcionalidade do ato exigir autorização ou controle jurisdicional ou ainda quando o sujeito passivo estiver sofrendo restrições no seu direito de defesa, à prova, acesso aos autos, etc., por parte do investigador". ${ }^{143}$

Nos dizeres de Antonio Sérgio Altiere de Moraes Pitombo, o estabelecimento da figura do juiz de garantias na frase pré-processual resulta em um aprimoramento da proteção do indivíduo, seja suspeito ou investigado, e até mesmo da vítima. ${ }^{144}$

Portanto, ainda que a função de garantidor dos direitos fundamentais não aparente se tratar de uma função progressista para com o atual modelo, merece destaque pela própria redação do novel diploma em seu artigo 14, ao suscitar de maneira manifesta esse mister de garantidor dos direitos fundamentais.

Com isso, resta consagrado o sistema acusatório na investigação preliminar, bem como a observância do devido processo legal que, como já defendido no bojo do trabalho, incide inquestionavelmente na fase de investigação preliminar.

\footnotetext{
${ }^{143}$ LOPES JÚNIOR, Aury; RITTER, Ruiz. Op. cit., p. 14.

${ }^{144}$ PITOMBO, Antonio Sérgio Altiere de Moraes. Criar função do juiz de garantias é aprimorar proteção do indivíduo. Disponível em <https://www.conjur.com.br/2017-mai-21/criar-funcaojuiz-garantias-aprimorar-protecao-individuo>. Acesso em 15 abr. 2019.
} 


\subsubsection{OTIMIZAÇÃO DA INVESTIGAÇÃO E INSTRUÇÃO PROCESSUAL}

A especialização na matéria que é levada a cabo pelo juiz de garantias na fase de investigação preliminar é uma forma indubitável de otimizar a investigação, vez que o magistrado se encontrará mais familiarizado com a temática, atuando portanto com maior expertise na matéria que é de sua competência.

Antonio Sérgio Altiere de Moraes Pitombo, ao dispor sobre a relevância do tema fazendo alusão às Varas de Inquérito na cidade de São Paulo - SP, indaga:

"A experiência mostrou na Comarca de São Paulo as vantagens de se formar um grupo de juízes, com competência para controlar a legalidade de inquéritos policiais e atos da polícia judiciária. Depois de tantos anos, parece difícil contestar a importância de se ter um juiz criminal dedicado a resolver questões inerentes ao inquérito policial." 145

Apesar de referir-se a instituto diferente, qual seja, juiz de vara de inquérito e não juiz de garantia, a mesma premissa que é endossada para um pode ser para o outro: a de que o aprofundamento na matéria é um passo importante para uma investigação mais técnica e célere, devido à expertise na matéria.

Mauro Fonseca Andrade traz a cabo uma importante discussão sobre a matéria ao inferir que a especialização decorrente da atuação delimitada do juiz de garantias tem o condão de ser efetiva e enérgica em comarcas de médio e grande porte. ${ }^{146}$

Sob outro prisma, mas não menos importante, além da otimização da investigação pelo aperfeiçoamento da matéria, haverá também uma maior celeridade para o julgamento dos processos, vez que os juízes das varas criminais poderão:

\footnotetext{
145 Ibid.

${ }^{146}$ ANDRADE, Mauro Fonseca. Op. cit., p. 68. Para o autor, no que tange às varas de pequeno porte, não haveria a otimização, vez que a prestação jurisdicional "já é célere pela baixa quantidade de feitos a serem julgados.” Ibid. p. 68.
} 
"dedicar-se exclusivamente à condução cuidadosa e célere do processo criminal, assegurando os direitos das partes de postulação e instrução e proferindo a sentença criminal válida e justa em prazo razoável." ${ }^{147}$

Isso porque atualmente, a exemplo do que ocorre nas varas criminais federais, as secretarias das varas se subdividem entre o processamento de incidentes pré-processuais e congêneres relativos à investigação preliminar e o processamento das ações penais. ${ }^{148} \mathrm{O}$ que gera, estreme de dúvidas, um maior acervo de trabalho tanto para os magistrados quanto para os serventuários da justiça, prejudicando o normal andamento dos feitos e, por conseguinte, a prestação jurisdicional efetiva e célere.

Tendo em vista essa premissa, Luiz Flávio Gomes compreende que “como teríamos um juiz voltado exclusivamente para a investigação, estima-se que isso se traduza em maior especialização e, portanto, ganho de celeridade. "149

Outrossim, além de garantir uma especialização do magistrado no tópico da fase pré-processual, a implantação do juiz de garantias também se irradia no campo da ação penal, ajudando a amenizar o contingente de procedimentos investigatórios em trâmite nas varas criminais, criando desta maneira uma maior celeridade na instrução criminal, em consonância com a duração razoável do processo, esculpida no artigo $5^{\circ}$, LXXVIII da CRFB. ${ }^{150}$

\subsubsection{AFASTAMENTO DO JUIZ CONTAMINADO}

O tema do afastamento do magistrado contaminado pela resolução de incidentes que clamam pela cláusula de reserva de jurisdição na fase da

\footnotetext{
${ }^{147}$ SCHREIBER, Simone. Op. cit., p. 03.

${ }^{148}$ Ibid. p. 03.

${ }^{149}$ GOMES, Luiz Flávio. O juiz das garantias projetado pelo novo CPP. Disponível em $<$ https://professorlfg.jusbrasil.com.br/artigos/121917615/o-juiz-das-garantias-projetado-pelonovo-cpp>. Acesso em 15 abr. 2019.

${ }^{150}$ Art. $5^{\circ}$ LXXVIII - a todos, no âmbito judicial e administrativo, são assegurados a razoável duração do processo e os meios que garantam a celeridade de sua tramitação.
} 
investigação preliminar é, sem sombra de dúvidas, uma das maiores revoluções no novel Código de Processo Penal sendo, por isso, merecedor de um maior enfoque, não só sob o prisma jurídico, como também sob o prisma da psicologia.

O diálogo com matérias de outros ramos das ciências sociais, ciências políticas e da medicina contribuem muitas vezes para a própria compreensão de institutos que não podem ser analisados apenas sob o prisma da dogmática do direito, sob pena de criação de institutos voltados apenas ao mundo jurídico, sem respaldo e certificação de efetividade dos outros ramos de pesquisa.

Pois bem.

A psicanálise em muito ajuda a compreender o motivo do afastamento do juiz que atuou na fase pré-processual do processo de conhecimento. Nesse sentido, nos esclarece Denise Luz e Leon Murelli Silveira que:

"A psicanálise explica que o envolvimento na investigação implica em um
investimento psíquico na tarefa inquisitiva. Isso acarreta em construções
racionais e atribuições de valores e afetos na tomada de decisão. Todas essas
representações são internalizadas e negadas ao se tentar exercitar a neutralidade
em um esforço consciente, mas podem emergir como conteúdos inconscientes
deslocados a engatilhar mecanismos de defesa que tornam o juiz predisposto a
continuar a linha de afetos, pensamentos e investimentos pulsionais que traz da
investigação: a tese da acusação criada na inquisição".

Fato é que não somos capazes de controlar aspectos inconscientes de nosso ego que, infalivelmente, emergirão em algum momento. E quando o juiz é chamado a atuar na fase preliminar, observando somente o lado da acusação - fruto da ausência da ampla defesa no procedimento -, sua interpretação da realidade será influenciada pelos argumentos da acusação, pois internaliza sua percepção sobre o caso sendo analisado, das responsabilidades e envolvimentos dos agentes integrantes do polo passivo. $^{152}$

\footnotetext{
${ }^{151}$ LUZ, Denise; SILVEIRA, Leon Murelli. Op. cit., p. 16.

${ }^{152}$ Ibid. p. 23/24.
} 
Então, após inúmeras decisões no plano pré-processual, com o deferimento de várias medidas de caráter restritivo aos direitos fundamentais do investigado e, quiçá, inclusive a decretação de prisão temporária ou preventiva, torna-se uma tarefa muito árdua para o juiz, dedicado ao trabalho $\mathrm{e}$ inspirado pelos ditames da justiça, a conscientização de que todas essas medidas podem ter, de algum modo, afetado um investigado que, na verdade, era inocente. ${ }^{153}$

Esclarecem os autores supramencionados que, nessa fase de tentativa de conscientização que o sujeito é na verdade inocente, o juiz:

"para proteger o aparelho psíquico desse sofrimento insuportável, o ego lança mão do mecanismo de defesa que age inconscientemente, livrando o sujeito (juiz) da angústia; Então, ele desloca a importância de representação para confirmar a correção da medida anterior, a prisão, no exemplo dado, permitindo ao sujeito-juiz se autoabsolver, mediante a convicção de ter adotado a medida correta e ter sido justo. Com isso, não concede o benefício da dúvida ao acusado, e, sem saber, faz talho da presunção de inocência". ${ }^{154}$

Outro aspecto interessante a influir na psique do magistrado é a libido, entendida como a "energia das pulsões sexuais (força que exerce pressão no aparelho psíquico)". ${ }^{155}$

Contudo, as pessoas podem investir a libido em outras situações alheias à sua sexualidade. Exemplo dessa situação é a de uma autoridade policial, que investe a sua libido no trabalho e, após se debruçar muito sobre uma investigação, obtém o gozo através da condenação do agente investigado por ele. ${ }^{156}$

O juiz também não está imune à esse fenômeno. Isso porque:

"Do mesmo modo que o policial, o juiz que se envolve no inquérito não está imune a esse fenômeno, precisando empregar um esforço psíquico em negar-se esse gozo para oferecer, substancialmente, e não como mera formalidade, igual oportunidade de defesa ao réu. (...) se ao encerrar o processo, o juiz puder confirmar que a decisão de prender e manter preso foi acertada e justa, ele tende a obter o gozo, a sensação prazerosa de satisfação pelo "dever cumprido". Ao contrário, a constatação de que a decisão de mandar prender possa ter sido

\footnotetext{
${ }^{153}$ Ibid. p. 26.

${ }^{154}$ Ibid. p. 26.

${ }^{155}$ Ibid. p. 27.

${ }^{156}$ Ibid. p. $28 / 29$.
} 
equivocada e injusta, exige do aparelho psíquico que negue o gozo a si mesmo, que se autoimponha o desprazer, a frustração". ${ }^{157}$

Em assim sendo, a absolvição do acusado pode demonstrar a falibilidade do Estado-Juiz o que, para sujeitos que se auto exigem muito, pode demonstrar um ataque à sua imagem. ${ }^{158}$

Por isso a necessidade tão alta de afastar o juiz contaminado na fase pré-processual da ação penal, pois "ninguém consegue passar imune a si mesmo, nem o juiz". ${ }^{159}$

Outra contribuição que dialoga com outras ciências e merece destaque é a teoria da dissonância cognitiva e do efeito primazia. Aquela é definido como um "estudo acerca da cognição e do comportamento humano" ${ }^{160}$, e esta como a revelação de que as informações posteriores sobre um indivíduo:

"são, em geral, consideradas no contexto de informação inicial recebida, sendo esta a responsável pelo direcionamento da cognição formada a respeito da respectiva pessoa e pelo comportamento que se tem para com ela". ${ }^{161}$

A função do juiz que atua na fase preliminar e julga o feito não corresponde a um acúmulo de papéis, e sim a um conflito de papéis, pois o juiz que atua na investigação preliminar constrói uma imagem mental sobre os fatos e, ao receber a denúncia, incorre inevitavelmente em prejulgamento. $^{162}$

Isso porque toda pessoa, incluindo o magistrado:

"procura um equilíbrio do seu sistema cognitivo, uma relação não contraditória. A tese de defesa gera uma relação contraditória com as hipóteses iniciais (acusatórias) e conduz à (molesta) dissonância cognitiva. Como consequência existe o efeito inércia ou perseverança, de autoconfirmação das hipóteses, por meio de busca seletiva de informações". ${ }^{163}$

\footnotetext{
${ }^{157}$ Ibid. p. 29.

${ }^{158}$ Ibid. p. 30.

${ }^{159}$ Ibid. p. 33.

${ }^{160}$ LOPES JÚNIOR, Aury; RITTER, Ruiz. Op. cit., p. 17.

${ }^{161}$ Ibid. p. 19.

162 Ibid. p. 21.

${ }^{163}$ Ibid. p. 22.
} 
Pelo efeito inércia ou perseverança, compreende-se um mecanismo de autoafirmação das hipóteses, supervalorizando informações obtidas anteriormente - como na investigação preliminar - e as considerando como corretas. Já a busca seletiva de informações é entendida como a busca de informações que confirmem as hipóteses previamente aceitas pelo juiz, que gera o efeito confirmador-tranquilizador em sua pessoa. ${ }^{164}$

Resta, pois, diante dos diálogos com as outras ciências, notadamente a psicanálise e a psicologia social, comprovada a necessidade de afastamento do juiz atuante na fase de investigação preliminar do juiz que atuará na ação penal, como medida garantidora da manutenção de sua necessária imparcialidade.

\subsection{ASPECTOS CONTROVERTIDOS DO JUIZ DE GARANTIAS}

É natural que, sempre quando há a tentativa de implementação de um novo instituto, diversas críticas sobre a sua função, necessidade e compatibilidade são trazidas à baila, seja por doutrinadores pátrios, seja por órgãos do próprio Poder Judiciário, Ministério Público, Defensoria Pública e Poder Executivo.

$\mathrm{O}$ que vemos no caso em comento não é diferente. Há algumas críticas muito bem elaboradas por parte desses atores, que serão agora explicitadas e rebatidas, com o intuito de obter no projeto final um instituto puro, que irradie todos os comandos normativos da Constituição Federal.

Passa-se à primeira crítica. De maneira mais singela que as demais, há a crítica sobre a redação do artigo $15^{165}$ do novel diploma, que determina o afastamento do juiz de garantias no momento da propositura da ação penal, e não após o seu recebimento.

\footnotetext{
${ }^{164}$ Ibid. p. 21.

${ }^{165}$ Art. 15. A competência do juiz das garantias abrange todas as infrações penais, exceto as de menor potencial ofensivo e cessa com a propositura da ação penal.
} 
Ora, a decisão de recebimento da denúncia, ainda que pacificada na doutrina que não depende de motivação, exige do magistrado adentrar minimamente no exame dos elementos informativos ou provas colhidas na fase de investigação preliminar, logo, há uma aproximação do juiz da instrução com os elementos indiciários da investigação, o que denota um afastamento da linha teórica proposta na exposição de motivos do Anteprojeto. ${ }^{166}$

Portanto, a melhor solução seria que o próprio juiz de garantias fosse o responsável pelo recebimento ou não da denúncia, de modo a manter a imparcialidade do juiz responsável pela instrução processual e pelo julgamento do mérito. Corrobora esse entendimento também o fato de o juiz de garantias estar em contato com a investigação preliminar, ser mais especializado sobre a matéria da investigação, o que leva a um maior respaldo técnico para decidir sobre a formalização ou não da ação penal. ${ }^{167}$

Outro ponto a ser criticado e que requer uma solução mais enérgica é o da prevenção do Tribunal responsável pelo julgamento de recursos na fase da investigação preliminar, pois:

"se por um lado, com o juiz de garantias, se alcança o ponto crítico da fase préprocessual, por outro, esse instituto, por si só, não alcança o problema gerado pela regra da prevenção em segunda instância, decorrente do conhecimento e julgamento de medidas recursais e de habeas corpus impetrado contra atos praticados pelo juiz durante a investigação ou instrução criminal." 168

A necessidade de ser afastada a prevenção também nos tribunais é de suma importância, tendo em vista que via de regra as ações penais são decididas definitivamente nos tribunais de apelação e, por isso, é mister medidas proativas de modo a blindar a imparcialidade dos julgadores também em segunda instância. ${ }^{169}$

\footnotetext{
${ }^{166}$ MAYA, André Machado. Op. cit., p. 228.

${ }^{167}$ Ibid. p. 228/229.

168 Ibid. p. 231.

${ }^{169}$ Ibid. p. 231.
} 
A prevenção em segunda instância não encontra respaldo legal da análise dos artigos 52 a 56 do $\mathrm{PL}^{170}$, que tratam sobre as hipóteses de impedimento e suspeição dos juízes e dos órgãos colegiados, vez que em nenhum momento criam uma cláusula de impedimento ou suspeição dos julgadores recursais que tiverem decidido questões incidentais ou ações de impugnação autônoma ainda na fase pré-processual.

Apesar de não ser objeto do presente trabalho a atuação em segunda instância, a mesma crítica sobre a prevenção dos magistrados que decidem algum incidente pré-processual na investigação vale aqui para o julgador de segundo grau, que está prevento desde a fase pré-processual até o julgamento da Apelação e o exaurimento da instância recursal.

Uma da soluções discutidas para esse tropeço do novo Código de Processo Penal em não afastar a regra de prevenção dos magistrados de segunda instância é trazida por André Machado Maya, para quem:

"Seguindo a mesma linha do juiz de garantias, uma das possibilidades no âmbito dos julgamentos colegiados da fase recursal é a criação de um juizado de garantias, um órgão jurisdicional inserido na estrutura dos tribunais de segunda instância e competente exclusivamente para o reexame de todos e quaisquer atos decisórios proferidos pelo juiz de garantias durante a

\footnotetext{
${ }^{170}$ Art. 52. Ao juiz incumbirá zelar pela legalidade do processo e manter a ordem no curso dos respectivos atos.

Art. 53. O juiz estará impedido de exercer jurisdição no processo em que: I- tiver funcionado seu cônjuge, companheiro ou parente, consanguíneo ou afim, em linha reta ou colateral, até o terceiro grau, inclusive, como defensor ou advogado, órgão do Ministério Público, delegado de polícia, auxiliar da justiça ou perito; II - ele próprio houver desempenhado qualquer dessas funções ou servido como testemunha; III - tiver funcionado como juiz de outra instância, pronunciando-se, de fato ou de direito, sobre a questão; IV - ele próprio ou seu cônjuge, companheiro ou parente, consanguíneo ou afim em linha reta ou colateral, até o terceiro grau, inclusive, for parte ou diretamente interessado no feito.

Art. 54. Nos juízos colegiados, estarão impedidos de atuar no mesmo processo os juízes que forem entre si cônjuges, companheiros ou parentes, consanguíneos ou afins, em linha reta ou colateral até o terceiro grau, inclusive.

Art. 55. Em caso de suspeição, o juiz poderá ser recusado pelas partes. $\S 1^{\circ}$ Reputa-se fundada a suspeição quando o juiz manifestar parcialidade na condução do processo ou no julgamento da causa e, ainda, nas seguintes hipóteses: I - se mantiver relação de amizade ou de inimizade com qualquer das partes; 14 II - se ele, seu cônjuge, companheiro, ascendente, descendente ou irmão estiver respondendo a processo por fato análogo, sobre cujo caráter criminoso haja controvérsia; III - se ele, seu cônjuge, companheiro ou parente, consanguíneo ou afim, até o terceiro grau, inclusive, sustentar demanda ou responder a processo que tenha de ser julgado por qualquer das partes; IV-se tiver aconselhado qualquer das partes; $V$ - se mantiver relação jurídica de natureza econômica ou moral com qualquer das partes, da qual se possa inferir risco à imparcialidade; VI - se tiver interesse no julgamento da causa em favor de uma das partes. $\S$ $2^{\circ}$ O juiz, a qualquer tempo, poderá se declarar suspeito, inclusive por razões de foro íntimo. Art. 56. A suspeição não poderá ser declarada nem reconhecida quando a parte de propósito der motivo para criá-la.
} 
investigação preliminar e, também, dos atos decisórios proferido pelo juiz singular durante a instrução criminal." ${ }^{, 171}$

Portanto, apesar de haver uma lacuna legislativa no PL sobre a prevenção dos órgãos colegiados no julgamento de segundo grau, parece a melhor opção a destacada acima sobre a criação de um juizado de garantias dentro da segunda instância, de modo a garantir o princípio da imparcialidade e o devido processo legal também na atuação recursal.

No entanto, a crítica que merece maior destaque, por ser a de mais difícil solução, é com relação à inviabilidade operacional da instituição do juiz de garantias, notadamente nas comarcas pequenas e distantes de grandes metrópoles.

Outrossim, o Conselho Nacional de Justiça emitiu a Nota Técnica $\mathrm{n}^{\text {o }} 10$ de 17/08/2010, aprovada pela unanimidade do plenário do CNJ, dispondo sobre críticas e elogios à reforma do Código de Processo Penal, sendo o documento enviado para o Senado Federal.

Indubitavelmente, o item mais importante da Nota Técnica é o item 8, in verbis:

"8. O Projeto, preocupando-se com a consolidação de um modelo acusatório, institui a figura do 'juiz das garantias', que será o responsável pelo exercício das funções jurisdicionais alusivas à tutela imediata e direta das inviolabilidades pessoais, sob duas preocupações básicas, segundo a exposição de motivos, a saber: a de otimizar a atuação jurisdicional criminal e a de manter o distanciamento do juiz incumbido de julgar o processo. Contudo, a consolidação dessa ideia, sob o aspecto operacional, mostra-se incompatível com a atual estrutura das justiças estadual e federal. O levantamento efetuado pela Corregedoria Nacional de Justiça no sistema Justiça Aberta revela que $40 \%$ das varas da Justiça Estadual no Brasil constituem-se de comarca única, com apenas um magistrado encarregado da jurisdição. Assim, nesses locais, sempre que o único magistrado da comarca atuar na fase do inquérito, ficará automaticamente impedido de jurisdicionar no processo, impondo-se o deslocamento de outro magistrado de comarca distinta. Logo, a adoção de tal regramento acarretará ônus ao já minguado orçamento da maioria dos judiciários estaduais quanto ao aumento do quadro de juízes e servidores, limitados que estão pela Lei de Responsabilidade Fiscal, bem como no que tange ao gasto com deslocamentos e diárias dos magistrados que deverão atender outras comarcas. Ademais, diante de tais dificuldades, com a eventual implementação de tal medida haverá riscos ao atendimento do princípio da razoável duração do processo, a par de um perigo iminente de prescrição de muitas ações penais. Também é necessário anotar que há outros motivos de

${ }^{171}$ Ibid. p. 232. 
afastamentos dos magistrados de suas unidades judiciais, como nos casos de licença, férias, convocações para Turmas Recursais ou para composição de Tribunais." $" 172$

Mauro Fonseca Andrade assinala que, em consonância com a Nota Técnica, haverá um impacto financeiro tão robusto que a verba orçamentária destinada aos tribunais estaduais não será suficiente para suportar, seja pela criação de varas especializadas, seja pelas diárias e os deslocamentos pagos aos magistrados. ${ }^{173}$

Entretanto, setores da doutrina buscaram soluções para esse problema efetivo e considerável para o instituto. A primeira solução tangencia a modernização dos procedimentos investigatórios com a viabilização do sistema de processo eletrônico nesta fase.

Denise Luz e Leon Murelli Silveira assim destacam:

"No que tange à Justiça Federal, praticamente, todas as seções judiciarias já estão usando o sistema de processo eletrônico - E-Proc. Por esse sistema, não faz sentido que se exija a presença física do juiz, permanentemente, para analisar o inquérito e decidir. A Justiça Estadual deve caminhar para o mesmo rumo, o da modernização dos procedimentos."

Além da primeira solução de implantação do inquérito eletrônico, a segunda pode ser observada a partir da regionalização do juiz de garantias, "de modo que um único juiz de garantias atenda a um grupo de comarcas próximas". ${ }^{175}$

No mesmo norte, "Poder-se-ia, por exemplo, implementar varas regionalizadas com um juiz de garantias atendendo várias comarcas próximas. "176

\footnotetext{
172 BRASIL. Conselho Nacional de Justiça. Nota Técnica n. 10/2010. Disponível em $<$ http://www.cnj.jus.br/atos-administrativos?documento=225>. Acesso em 23 abr. 2019.

${ }^{173}$ ANDRADE, Mauro Fonseca. Op. cit., p. 72. Contudo, logo em seguida, o autor destaca que esses óbices podem ser eliminados, posto que "não há como fechar os olhos para o fato de o processo eletrônico simplesmente pulverizar o argumento das distâncias entre comarcas e dos diminutos orçamentos dos Poderes Judiciários estaduais. ” Ibid. p. 73

${ }^{174}$ LUZ, Denise; SILVEIRA, Leon Murelli. Op. cit., p. 20.

${ }^{175}$ LOPES JÚNIOR, Aury; RITTER, Ruiz. Op. cit., p. 24.

${ }^{176}$ LUZ, Denise; SILVEIRA, Leon Murelli. Op. cit., p. 21.
} 
Com isso, demonstra-se a priori que, apesar de ser uma crítica muito importante ao instituto, soluções práticas e de baixo dispêndio orçamentário parecem terem sido encontradas.

Basta agora apenas um mínimo de vontade para levar as soluções existentes adiante. ${ }^{177}$

Não se pode invocar questões burocráticas e orçamentárias para deixar de instituir um marco tão importante para o processo penal e o sistema acusatório no Brasil. Nesse sentido, Luiz Flávio Gomes ressalta:

"Claro que alguns tribunais alegarão razões orçamentárias para não se implantar o juiz das garantias, mas quem acha que isso representa um alto custo é porque ainda não parou para quantificar o prejuízo que vem causando o sistema atual, que tem dado ensejo a muitos e exorbitantes abusos (que geram nulidades), sem contar o desprestígio para a própria justiça criminal (que é posto em relevo pela mídia, influenciando a percepção negativa da população quanto ao funcionamento da Justiça). Nada disso, evidentemente, contribui para o aprimoramento do nosso Estado constitucional e humanista de direito, fundado na legalidade, constitucionalidade e convencionalidade do seu ordenamento jurídico." 178

Isto deve ser feito e as soluções discutidas e implementadas, posto que "eventuais dificuldades burocráticas e operacionais de implementação da medida não devem ser invocadas para sua rejeição" criminal mais justa, garantista e eficiente. "180

\subsection{O ATUAL TRÂMITE DO PROJETO DE LEI NN 8045/2010}

O PL do novel diploma processual penal encontra-se atualmente em trâmite perante a Câmara dos Deputados, sendo oriundo do PLS 145/2009 do Senado Federal.

Observa-se, outrossim, que o Projeto de Lei se prolonga durante aproximadamente 10 (dez) anos em nosso Congresso Nacional, sem

\footnotetext{
${ }^{177}$ LOPES JÚNIOR, Aury; RITTER, Ruiz. Op. cit., p. 24.

${ }^{178}$ GOMES, Luiz Flávio. O juiz das garantias projetado pelo novo CPP. Disponível em $<$ https://professorlfg.jusbrasil.com.br/artigos/121917615/o-juiz-das-garantias-projetado-pelonovo-cpp>. Acesso em 23 abr. 2019.

${ }^{179}$ SCHREIBER, Simone. Op. cit., p. 03.

${ }^{180}$ Ibid. p. 03.
} 
contudo possuir qualquer previsão de término, seja para sua aprovação, seja para seu arquivamento.

Para dificultar a tramitação célere do PL, que atualmente encontrase "Aguardando Constituição de Comissão Temporária pela Mesa", há exatos 281 Projetos de Lei apensados por existência de vínculo e correlação entre as matérias, bem como 226 emendas e 135 requerimentos. $^{181}$

Dentre as inúmeras movimentações dentro da Câmara dos Deputados, houve a realização de audiências públicas com inúmeros processualistas penais, entidades e associações de renome para a discussão sobre o projeto.

Por possuir muitos artigos em seu corpo, foram designados relatores parciais, responsáveis por proferir pareceres sobre a constitucionalidade, juridicidade e adequação legislativa de partes específicas do código e suas emendas respectivas, a saber, (i) $1^{\text {a }}$ Relatoria Parcial (arts. $1^{\circ}$ ao 164): Deputado Rodrigo Pacheco; (ii) $2^{\mathrm{a}}$ RelatoriaParcial (arts. 165 ao 320): Deputado Rubens Pereira Junior; (iii) $3^{\mathrm{a}}$ Relatoria-Parcial (arts. 321 ao 457): Deputado Pompeo de Mattos; (iv) $4^{\text {a }}$ Relatoria-Parcial (arts. 458 ao 611): Deputado Paulo Teixeira e; (v) $5^{\text {a }}$ Relatoria-Parcial (arts. 612 ao 756): Deputada Keiko Ota. ${ }^{182}$

O que nos importa aqui, por evidente, é o voto sobre a $1^{\mathrm{a}}$ Relatoria Parcial, de lavra do ex-deputado Rodrigo Pacheco, eis que possui atribuição para se manifestar sobre o juiz de garantias, posto que esta figura está inserida entre os artigos 1 ao 164 do novel diploma, mais especificamente nos artigos 14 ao 17 .

\footnotetext{
${ }^{181}$ Informações disponíveis no site oficial da Câmara dos Deputados. Disponível em: $<$ https://www.camara.leg.br/proposicoesWeb/fichadetramitacao?idProposicao=490263 $>$. Acesso em 02 mai. 2019.

${ }^{182}$ CÂMARA DOS DEPUTADOS DO BRASIL. Comissão Especial Destinada A Proferir Parecer Ao Projeto De Lei No 8045, De 2010. Relatório Parcial $4^{a}$ Relatoria-Parcial. Disponível em:

$<$ https://www.camara.leg.br/proposicoesWeb/prop_mostrarintegra?codteor $=1635092 \&$ filename $=$ Tramitacao-PRP+1+PL804510+\%3D\%3E+PL+8045/2010.> p. 02. Acesso em 02 mai. 2019.
} 
Nesse ponto, eis a conclusão do voto do relator parcial Rodrigo Pacheco sobre a matéria, que data do dia 17.08.2017:

"1 - constitucionalidade, juridicidade e adequada técnica legislativa da parte do Projeto de Lei ${ }^{\circ}$ 8.045, de 2010 (referente ao Livro 1 (Da Persecução Penal), abrangendo os seguintes Títulos: Título 1 (Dos princípios fundamentais); Título II (Da investigação criminal); Título III (Da ação penal); Título IV (Dos sujeitos do processo); Título V (Dos direitos da vítima); Título VI (Da competência) e Título VII (Dos atos processuais) - Artigos $1^{\circ}$ a 164), cuja relataria me foi atribuída e, no mérito, pela sua aprovação, com as emendas de Relator-Parcial apresentadas ao final. ${ }^{183}$

Atestando a importância da figura do juiz de garantias, o relator parcial, ao rejeitar emendas ao PL contrárias ao instituto, vaticinou:

"A figura do juiz das garantias é fulcral para o bom funcionamento do sistema de justiça criminal. (...) É inegável que o juiz das garantias representa um avanço do processo penal brasileiro, especialmente porque busca impedir a contaminação do juiz do processo com as provas produzidas sem o devido contraditório e ampla defesa próprio da fase de persecução policial, além de evitar o contato com aquelas provas produzidas ilegalmente, ao arrepio da lei e da Constituição. Por meio da instituição do juiz das garantias, o legislador deixa explícito seu compromisso com a ideia de que todo o desenvolvimento processual, a todo tempo e em todas as fases, deve estar comprometido com os direitos fundamentais da pessoa humana." 184

Além do então deputado Rodrigo Pacheco, os deputados Rubens Pereira Júnior, Pompeo de Mattos, Paulo Teixeira e Keiko Ota também proferiram pareceres pela constitucionalidade, juridicidade e adequada técnica legislativa de suas partes específicas do PL. ${ }^{185}$

Contudo, há ainda muito o que percorrer para a aprovação do novo Código de Processo Penal. Fato é que sua aprovação, como qualquer outro Projeto de Lei, depende de muitos fatores externos e internos às casas legislativas, bem como do momento político experimentado pela nossa sociedade.

\footnotetext{
${ }^{183}$ CÂMARA DOS DEPUTADOS DO BRASIL. Comissão Especial Destinada A Proferir Parecer Ao Projeto De Lei $\mathrm{N}^{\circ}$ 8045, De 2010. $1^{\circ}$ Relatório Parcial. Disponível em: $<$ https://www.camara.leg.br/proposicoesWeb/prop_mostrarintegra?codteor $=1671395 \&$ filename $=$ $\mathrm{PRP}+5+\mathrm{PL} 804510+\% 3 \mathrm{D} \% 3 \mathrm{E}+\mathrm{PL}+8045 / 2010>$. p. 149/150. Acesso em 02 mai. 2019.

${ }^{184}$ Ibid. p. 99.

${ }^{185}$ Informações disponíveis no site oficial da Câmara dos Deputados. Disponível em: $<$ https://www.camara.leg.br/proposicoesWeb/prop_pareceres_substitutivos_votos;jsessionid=FE 1D556131E9B02468AB9C6F0A1F839B.proposicoesWebExterno2? idProposicao=490263 $>$.

Acesso em 02 mai. 2019.
} 
$\mathrm{Na}$ atual conjuntura, não parece ser possível enxergar no horizonte a aprovação do presente PL. Isso porque há, hoje em dia, tramitando pelas casas legislativas, Projetos de Lei com maior ênfase de votação - a exemplo do "Projeto Anticrime" - que possuem uma prioridade maior de tramitação diante do maior clamor popular e do alinhamento com o viés ideológico do alto escalão do atual Governo Federal. ${ }^{186}$

Assim sendo, afastando a ingenuidade e o romantismo da atividade legiferante nacional, a promulgação de um novo Código de Processo Penal irradiado pela Constituição Federal, que promove os direitos e garantias fundamentais do sujeito passivo da investigação e do processo não parece ter sustentáculo e nem prioridade na atualidade, lamentavelmente.

\subsection{PAÍSES QUE ADOTAM A FIGURA DO JUIZ DE GARANTIAS}

Não se pretende neste subcapítulo vaticinar única e exclusivamente sobre países que adotam a figura do juiz de garantias. O que se almeja aqui é trazer à tona países que, diante de atuais reformas legislativas, buscaram direcionar seus sistemas processuais penais a um viés acusatório, em respeito às garantias e direitos fundamentais, bem como de garantir a imparcialidade do juiz, muitas vezes afastando regras de prevenção na transição da fase de investigação para a processual, outrora usuais em seus ordenamentos.

Imperioso ressaltar também que não há como afirmar que algum país possua um juiz de garantias tal qual o delineado pela PL $\mathrm{n}^{\circ}$ $8045 / 2010$. Até porque a figura do juiz de garantias, como disposta no novel CPP, é uma disposição sui generis de nosso Parlamento, refletindo o posicionamento de nossos doutrinadores e representantes do povo, adaptado à realidade de nosso Poder Judiciário.

\footnotetext{
${ }^{186}$ Também pode ser citado como exemplo o PL 4850/2016, referente às "10 Medidas Contra a Corrupção", dentre outros.
} 
O que se almeja aqui, portanto, é trazer à baila como alguns países, mormente os europeus e latino-americanos, lidam com a questão da preservação da imparcialidade do juiz durante a passagem da investigação preliminar para a ação penal, da prevenção do juiz, bem como da função que o juiz possui na fase pré-processual e, por último, como os países vêm adotando o sistema acusatório em seus ordenamentos jurídicos.

Nesse passo, Aury Lopes afirma:

"Os prejuízos de se ter um mesmo juiz participando da fase pré-processual e posteriormente do juízo oral, decidindo o caso penal, são evidentes e já foram objeto de inúmeras decisões pelo Tribunal Europeu de Direitos Humanos e causa de significativas mudanças legislativas em diversos países europeus (Espanha, Itália, Portugal e Alemanha, entre outros) e também na América Latina (...)" ${ }^{187}$

A começar pela Itália que, ao instituir seu Código de Processo Penal, extinguiu a figura do juizado de instrução, criando o giudice per le indagini preliminari, na qual o juiz possui a estrita posição de terceiro equidistante e estranho às partes envolvidas na fase pré-processual. ${ }^{188}$

Por isso, em linhas gerais, pode-se dizer que a proposta brasileira:

"se assemelha ao modelo do giudice per le indagini preliminari italiano, sobretudo em razão do fato de que esse juiz não tem função de juiz instrutor, não podendo exercer atividades que cabem ao investigador (...)". ${ }^{189}$

O que também pode ser observado na sistemática italiana é que sua Corte Constitucional, sob a luz dos julgados do TEDH e em decorrência de omissão legislativa sobre as regras de incompatibilidade do juiz, estabeleceu o princípio de que o juiz atuante na investigação preliminar está prevento e não poderá presidir o processo. ${ }^{190191}$

Também em Portugal, notadamente após a Revolução dos Cravos e consequente restauração da democracia -, houve o afastamento da figura

\footnotetext{
${ }^{187}$ LOPES JÚNIOR, Aury; RITTER, Ruiz. Op. cit., p. 13.

${ }^{188}$ ANDRADE, Mauro Fonseca. Op. cit., p. 62/78.

${ }^{189}$ LUZ, Denise; SILVEIRA, Leon Murelli. Op. cit., p. 19.

${ }^{190}$ CAVALCANTI, Danielle Souza de Andrade e Silva. Op. cit., p. 48.

${ }^{191}$ No mesmo sentido, André Machado Maya aduz que a Corte Constitucional italiana firmou jurisprudência no sentido de incompatibilizar a atuação sucessiva do magistrado em um mesmo procedimento penal. MAYA, André Machado. Op. cit., p. 219/220.
} 
do juiz de instrução, outrora importado do sistema penal francês, para então criar raízes de um processo penal verdadeiramente acusatório. ${ }^{192}$

Para tanto, o ordenamento lusitano deixou a cargo do Ministério Público a função investigatória, encarregando o juiz na fase préprocessual apenas do resguardo das liberdades individuais e das funções jurisdicionais respectivas. ${ }^{193}$

Trazendo para nossa realidade latino-americana, inúmeros países deste continente endossaram a figura do juiz de garantias, conforme preleciona André Machado Maya, para quem:

"No âmbito sul-americano, por sua vez, é possível observar um movimento de reformas processuais que acolhem, com algumas variações, a figura do juiz de garantias como um instrumento de aproximação das legislações processuais penais às exigências democráticas das mais variadas Constituições Federais. Foi assim no Chile, na Colômbia, no Paraguai e, também, em algumas províncias da Argentina, como Buenos Aires (...)" ${ }^{194}$

Merece destaque igualmente a recente alteração do Código de Processo Penal uruguaio (Lei 19.293, de 19 de dezembro de 2014) que, para Rômulo de Andrade Moreira:

"Assim como ocorrera no Chile há poucos anos (e, de resto, em toda a América Latina e a Central, a começar pela Guatemala), os uruguaios foram muito corajosos: passaram de uma estrutura inquisitorial, como a nossa, e hoje atuam sob as bases de um sistema acusatório".

Além da escolha explícita por um sistema acusatório, o novel diploma uruguaio também elencou o Ministério Público como responsável exclusivo pela investigação e entregou às partes a gestão da prova, afastando o juiz desse mister. ${ }^{196}$

Contudo, talvez o país latino-americano que mereça o maior destaque quanto à implementação da figura do juiz de garantias seja o Chile.

\footnotetext{
${ }^{192}$ MAYA, André Machado. Op. cit., p. 224.

${ }^{193}$ Ibid. p. $224 / 225$.

194 Ibid. p. 222/223.

${ }^{195}$ MOREIRA, Rômulo de Andrade. O que temos a aprender com o sistema processual penal do Uruguai. Disponível em: <https://www.conjur.com.br/2018-nov-28/romulo-moreira-precisamosaprender-processo-penal-uruguaio $>$. Acesso em 05 mai. 2019.

${ }^{196}$ Ibid.
} 
Isso porque Aury Lopes, ao asseverar sobre as mudanças legislativas ocorridas na América Latina, ressalta que "merecendo destaque a profunda e qualificada reforma realizada pelo Chile, onde foi consagrado na sua integralidade o "juiz das garantias",,197

Não à toa, dispõe o artigo 70 do Código de Processo Penal chileno:

“Artículo 70 .- Juez de garantía competente. El juez de garantía llamado por la ley a conocer las gestiones a que de lugar el respectivo procedimiento se pronunciará sobre las autorizaciones judiciales previas que solicitare el ministerio público para realizar actuaciones que privaren, restringieren o perturbaren el ejercicio de derechos asegurados por la Constitución."

\section{Em uma apertada síntese sobre o funcionamento procedimental do}

\section{Chile, Fernanda Ravazzano destaca:}

"são três etapas no processo chileno: o juízo de garantias (que pode ser precedido da audiência de detenção/custódia); a etapa intermediária (em que se analisará se as provas colhidas pela acusação - podendo também serem produzidas pela defesa - são legais e podem ser usadas no juízo oral); o juízo oral (fase instrutória, em que teremos o julgamento realizado por três juízes que não entraram em contato com a carpeta - processo - anteriormente, garantindose a imparcialidade)" ${ }^{199}$

Portanto, o juiz de garantias não será o responsável pelo

julgamento da causa, levando inclusive à nulidade absoluta da sentença, nos moldes do artigo 374, in verbis:

“Artículo 374.- Motivos absolutos de nulidad. El juicio y la sentencia serán siempre anulados: a) Cuando la sentencia hubiere sido pronunciada por un tribunal incompetente, o no integrado por los jueces designados por la ley; cuando hubiere sido pronunciada por un juez de garantía o con la concurrencia de un juez de tribunal de juicio oral en lo penal legalmente implicado, o cuya recusación estuviere pendiente o hubiere sido declarada por tribunal competente,",200

${ }^{197}$ LOPES JÚNIOR, Aury; RITTER, Ruiz. Op. cit., p. 13.

${ }^{198}$ CHILE. Norma: Ley 19696 Versión: Última Versión De: 01-Mar-2018 Fecha Publicación: 12Oct-2000 Fecha Promulgación: 29-Sep-2000. Establece Codigo Procesal Penal. Disponível em: $<$ https://www.leychile.cl/Navegar?idNorma=176595>. Acesso em 05 mai. 2019.

${ }^{199}$ RAVAZZANO, Fernanda. A experiência no Chile e a busca por um sistema acusatório no Brasil. Disponível em: <https://canalcienciascriminais.com.br/a-experiencia-no-chile-e-a-buscapor-um-sistema-acusatorio-no-brasil/>. Acesso em 05 mai. 2019.

${ }^{200}$ CHILE. Norma: Ley 19696 Versión: Última Versión De: 01-Mar-2018 Fecha Publicación: 12-Oct-2000 Fecha Promulgación: 29-Sep-2000. Establece Codigo Procesal Penal. Disponível em: <https://www.leychile.cl/Navegar?idNorma=176595>. Acesso em 05 mai. 2019. 
Outrossim, da análise do cenário internacional - tanto europeu quanto latino-americano - é facilmente perceptível o atraso do sistema processual penal brasileiro comparativamente com os referidos diplomas em garantir aos jurisdicionados um julgamento imparcial, e nos esteios de um sistema acusatório e garantidor do devido processo legal, como elencado por nossa Constituição da República Federativa do Brasil de 1988. 


\section{CONCLUSÃO}

O Código de Processo Penal atualmente vigente em nosso ordenamento não reflete, em alguns de seus dispositivos, os comandos normativos impostos pela Constituição da República Federativa do Brasil de 1988.

Inúmeros dispositivos do referido diploma processual possuem afinidade com o sistema processual inquisitivo, em inobservância à nossa Carta Maior, que optou por um sistema acusatório, com o fito de tutelar os direitos e garantias fundamentais do cidadão.

Dentre os artigos anacrônicos e retrógrados, podem ser destacados os que permitem ao juiz a instrução probatória com a possibilidade de produção de provas de ofício, a instauração de inquérito policial por sua requisição e a decretação da prisão preventiva de ofício no curso do processo.

Também merece destaque a previsão da regra de prevenção, sendo o juiz responsável pela atuação no inquérito policial ou procedimento investigatório criminal prevento para o julgamento do feito.

Há, portanto, uma clara afronta aos ditames constitucionais, notadamente na investigação preliminar, que esvaziam o sistema acusatório e o devido processo legal, prejudicando demasiadamente o princípio da imparcialidade.

O devido processo legal (due process of law) deve ser também estendido aos procedimentos administrativos que antecedem a ação penal, vez que podem gerar consequências nefastas ao indivíduo integrante do polo passivo, como a constrição de seus bens ou o cerceamento de sua liberdade ambulatorial.

É nesse passo que se assenta a presente dissertação, na necessidade de uma investigação preliminar irradiada pela Constituição Federal. 
Com efeito, o Projeto de Lei $\mathrm{n}^{\mathrm{o}}$ 8045/2010, que institui o novo Código de Processo Penal, possui uma aproximação salutar com o sistema acusatório e com a constitucionalização do processo penal.

Referido PL possui inúmeras disposições merecedoras de destaque, contudo, pela delimitação do trabalho em comento, foi abordada a sua incidência na fase da pré-processual, notadamente com a instituição da figura do juiz de garantias.

A figura supramencionada - vaticinada nos artigos 14 ao 17 do Projeto de Lei - representa a figura de um juiz atuante somente na fase preliminar até o oferecimento da denúncia.

Por possuir base ideológica fundada em um sistema acusatório conforme dicção do artigo $4^{\circ}$ do diploma - essa figura não se confunde com o juiz ou juizado de instrução, presente em alguns países europeus, ou com o juiz da vara de inquérito, presente em algumas cidades brasileiras.

Isso porque não possui uma função ativa na investigação. Noutras palavras, não se imiscui em atividades eminentemente investigatórias e administrativa-burocráticas, sendo convocado para atuar somente para garantir a legalidade da investigação e resguardar os direitos fundamentais do agente investigado, resolvendo incidentes que demandam a cláusula da reserva de jurisdição.

Por possuir uma atuação muito balizada, tão somente até o oferecimento da denúncia, traz também como consequência uma maior especialização na matéria pelo magistrado e, ademais, gera um ganho de celeridade no trâmite do feito, garantindo assim uma maior otimização da investigação preliminar.

Por atuar somente até a propositura da ação penal, afasta a vigente regra de prevenção, construindo a possibilidade de uma maior manutenção da imparcialidade do magistrado responsável pelo julgamento do feito. 
Não só as ciências jurídicas como diversas outras áreas do saber, mormente a psicologia, confirmam essa necessidade gritante de, para garantir a imparcialidade, afastar do julgamento um juiz que atuou com os elementos informativos da investigação preliminar, resolvendo seus respectivos incidentes e decretando medidas desfavoráveis ao investigado.

A figura do juiz de garantias possui críticas pertinentes, sendo a mais importante delas a emitida pela Nota Técnica $n^{\circ}$ 10/2010 do CNJ, sobre a impossibilidade orçamentária de sua implementação, principalmente levando em consideração as comarcas de vara única e distantes das capitais.

Apesar de muito pertinente, a doutrina nacional encontrou soluções práticas e de baixo custo para esse problema, como a implementação do inquérito eletrônico e da regionalização do juiz de garantias.

Contudo, apesar de solucionada a celeuma, é possível constatar que não há prioridade para a tramitação do novel diploma processual penal, que se estende por 10 (dez) anos, muito em razão do momento político vivido na contemporaneidade, com maior enfoque e clamor popular para outros Projetos de Lei.

Outrossim, percebe-se que o país caminha na contramão do mundo ocidental, que cada vez mais se direciona para a implementação de um sistema acusatório puro, muitas vezes afastando o juiz responsável pela investigação preliminar da instrução processual e julgamento do feito.

Grande exemplo dessa explanação na América do Sul é o Chile. Nosso conterrâneo latino institui a figura do juiz de garantias por excelência, de modo que, caso o juiz de garantias atue no julgamento do feito, levará à nulidade absoluta da sentença.

Portanto, não é forçoso concluir sobre a necessidade imprescindível do país em adotar o juiz de garantias como medida de manutenção da imparcialidade do julgador, garantindo assim o devido processo legal e o sistema acusatório em nosso ordenamento jurídico. 
Por isso, apesar de não ser a solução para todos os males decorrentes da quebra da imparcialidade, é uma solução que aperfeiçoa muito a prestação jurisdicional, garantindo ao sujeito passivo uma investigação preliminar com maior respeito aos direitos e garantias fundamentais, nos moldes de nossa Constituição Federal. 


\section{BIBLIOGRAFIA}

ANDRADE, Mauro Fonseca. Juiz das Garantias. Curitiba: Juruá, 2011.

ANDRADE, Mauro Fonseca. Sistemas processuais penais e seus princípios reitores. Curitiba: Juruá, 2008.

AQUINO, José Carlos Gonçalves Xavier; NALINI, José Renato. Manual de processo penal. 4. ed. São Paulo: Revista dos Tribunais, 2012.

BADARÓ, Gustavo Henrique Righi Ivahy. Processo Penal. 6. ed. São Paulo: Revista dos Tribunais, 2018.

BECCARIA, Cesare. Dos delitos e das penas. Tradução de Lucia Guidicini e Alessandro Berti Contessa. São Paulo: Martins Fontes, 1991.

BRASIL. Constituição, $1988 . \quad$ Disponível em $<$ http://www.planalto.gov.br/ccivil_03/constituicao/constituicao.htm>. Acesso em 27 mar. 2019.

BRASIL. Decreto-lei no 2.848, de 7 de dezembro de 1940. Disponível em $<$ http://www.planalto.gov.br/ccivil_03/decretolei/del2848compilado.htm>. Acesso em 16 mar. 2019.

BRASIL. Decreto-lei no 3.689, de 3 de outubro de 1941. Disponível em $<$ http://www.planalto.gov.br/ccivil_03/decretolei/del3689compilado.htm>. Acesso em 16 mar. 2019.

BRASIL. Supremo Tribunal Federal. Regimento Interno. Atualizado até a Emenda Regimental n. 51/2016: Brasília, 2019. Disponível em 
$<$ http://www.stf.jus.br/arquivo/cms/legislacaoRegimentoInterno/anexo/RI STF_ER_51_web.old.pdf>. Acesso em 01 abr. 2019.

BRASIL. Superior Tribunal de Justiça. Regimento Interno. Edição revista, ampliada e atualizada até a Emenda Regimental n. 30, de 22 de maio de 2018: Brasília, 2018. Disponível em $<$ https://ww2.stj.jus.br/publicacaoinstitucional//index.php/Regimento/artic le/view/3115/3839>. Acesso em 01 abr. 2019.

BRASIL. Superior Tribunal de Justiça. Súmula 533. Para o reconhecimento da prática de falta disciplinar no âmbito da execução penal, é imprescindível a instauração de procedimento administrativo pelo diretor do estabelecimento prisional, assegurado o direito de defesa, a ser realizado por advogado constituído ou defensor público nomeado. Terceira Seção, julgado em 10/06/2015, DJe 15/06/2015. Disponível em $<$ http://www.stj.jus.br/SCON/sumanot/toc.jsp?livre=(sumula\%20adj1\%20 \%27533\%27).sub.>. Acesso em 16 abr. 2019.

BRASIL. Conselho Nacional De Justiça. Nota Técnica n. 10/2010. Disponível em $\quad<$ http://www.cnj.jus.br/atosadministrativos?documento=225>. Acesso em 23 abr. 2019.

CÂMARA DOS DEPUTAdOS DO BRASIL. Código de Processo Penal. Disponível em $<$ https://www.camara.leg.br/proposicoesWeb/prop_mostrarintegra?codteo $\mathrm{r}=1638152 \&$ filename $=\mathrm{PL}+8045 / 2010>$. Acesso em 05 abr. 2019.

CÂMARA DOS DEPUTADOS DO BRASIL. Disponível em: $<$ https://www.camara.leg.br/proposicoesWeb/fichadetramitacao?idProposi $\mathrm{cao}=490263>$. Acesso em 02 mai. 2019. 
CÂMARA DOS DEPUTADOS DO BRASIL. Comissão Especial Destinada A Proferir Parecer Ao Projeto De Lei No 8045, De 2010. Relatório Parcial $4^{\mathrm{a}}$ Relatoria-Parcial. Disponível em: $<$ https://www.camara.leg.br/proposicoesWeb/prop_mostrarintegra?codteo $\mathrm{r}=1635092 \&$ filename $=$ Tramitacao-

PRP+1+PL804510+\%3D\%3E+PL+8045/2010>. Acesso em 02 mai. 2019.

CÂMARA DOS DEPUTADOS DO BRASIL. Comissão Especial Destinada A Proferir Parecer Ao Projeto De Lei No 8045, De 2010. $1^{\circ}$ Relatório Parcial. Disponível em: $<$ https://www.camara.leg.br/proposicoesWeb/prop_mostrarintegra?codteo $\mathrm{r}=1671395 \&$ filename $=\mathrm{PRP}+5+\mathrm{PL} 804510+\% 3 \mathrm{D} \% 3 \mathrm{E}+\mathrm{PL}+8045 / 2010>$. Acesso em 02 mai. 2019.

CÂMARA DOS DEPUTADOS DO BRASIL. Histórico de Pareceres, Substitutivos e Votos - PL 8045/2010. Disponível em: $<$ https://www.camara.leg.br/proposicoesWeb/prop_pareceres_substitutivo s_votos;jsessionid=FE1D556131E9B02468AB9C6F0A1F839B.proposico esWebExterno2?idProposicao=490263>. Acesso em 02 mai. 2019.

CARNELUTTI, Francesco. As Misérias do Processo Penal. Campinas, SP: Servanda Editora, 2016.

CARTA, Magna (Magna Charta Libertatum). Disponível em $<$ http://www4.policiamilitar.sp.gov.br/unidades/dpcdh/Normas_Direitos Humanos/MAGNA\%20CARTA\%20-\%20PORTUGU\%C3\%8AS.pdf $>$. Acesso em 27 mar. 2019.

CASARA, Rubens R. R. Mitologia processual penal. São Paulo: Saraiva, 2015. 
CASARA, Rubens R. R.. Vamos levar a imparcialidade judicial a sério? Disponível em <http://www.justificando.com/2019/02/27/vamos-levar-aimparcialidade-judicial-aserio/?fbclid=IwAR3zIwLsDx9aC5ALurF1JuAyBImW_iPGyM39Q_Ov8 9C5R9o8ZK-gXwsf1X8>. Acesso em 28 mar. 2019.

CAVALCANTI, Danielle Souza de Andrade e Silva. O Juiz de Garantias na Investigação Preliminar Criminal. In: BASTOS, Marcelo Lessa; AMORIM, Pierre Souto Maior Coutinho de (Orgs.). Tributo a Afrânio Silva Jardim: escritos e pareceres. Rio de Janeiro: Lumen Juris, 2011. p. $29 / 52$.

CHILE. Norma: Ley 19696 Versión: Última Versión De: 01-Mar-2018 Fecha Publicación: 12-Oct-2000 Fecha Promulgación: 29-Sep-2000. Establece Codigo Procesal Penal. Disponível em: $<$ https://www.leychile.cl/Navegar?idNorma=176595>. Acesso em 05 mai. 2019.

CHOUKR, Fauzi Hassan. Brasil. In: MAIER, Julio B. J.; AMBOS, Kai; WOISCHNIK, Jan (Orgs.). Las reformas procesales penales en América Latina. Buenos Aires: Ad-Hoc, 2000. p. 123/166.

CONFIM, Edilson Mougenot. Curso de processo penal. 7. ed. São Paulo: Saraiva, 2012.

COOLEY, Thomas M. Princípios gerais de direito constitucional nos Estados Unidos da América. Campinas: Russell \& Russell, 2002.

COUTINHO, Jacinto Nelson Miranda. Crítica à teoria geral do direito processual penal. Rio de Janeiro: Renovar, 2001. 
DUCLERC, Elmir. Curso Básico de Direito Processual Penal. 2. ed. vol. I. Rio de Janeiro: Lumen Juris, 2006.

ESTADOS UNIDOS DA AMÉRICA. Constituição dos Estados Unidos da América. Disponível em $<$ http://corvobranco.tripod.com/dwnl/constEUA.pdf $>$. Acesso em 27 mar. 2019.

ESTRASBURGO, Sentencia Del Tribunal Europeo De Derechos Humanos De. Caso Piersack Contra Bélgica 1 Octubre 1982. Disponível em <http://www.cienciaspenales.net/files/2016/10/6caso-piersack-contrabelgica-derecho-a-un-proceso-independiente-e-imparcial.pdf $>$. Acesso em 01 abr. 2019.

FEITOZA, Denilson. Direito processual penal: teoria, crítica e práxis. 7. ed. Niterói, RJ: Impetus, 2010.

GIACOMOLLI, Nereu José. $O$ devido processo penal: abordagem conforme a Constituição Federal e o Pacto de São José da Costa Rica. 3. ed. São Paulo: Atlas, 2016.

GOMES, Luiz Flávio. O juiz das garantias projetado pelo novo CPP. Disponível em <https://professorlfg.jusbrasil.com.br/artigos/121917615/ojuiz-das-garantias-projetado-pelo-novo-cpp>. Acesso em 08 abr. 2019.

GOMES, Luiz Flavio; BIANCHINI, Alice; DAHER, Flávio. Princípios Constitucionais Penais: à luz da Constituição e dos Tratados Internacionais. LivroeNet/Atualidades do Direito, 2015. Livro digital. 
GUIMARÃES, Johnny Wilson Batista. Imputação criminal preliminar e indiciamento: legitimidade e conformação constitucional. Belo Horizonte: Editora D’Plácido, 2017.

JARDIM, Afrânio Silva. Direito Processual Penal. 11. ed. Rio de Janeiro: Forense, 2007.

JORGE, Estêvão Luís Lemos. O contraditório no inquérito policial: à luz dos princípios constitucionais. Campinas, SP: Millennium Editora, 2015.

LIMA, Marcellus Polastri. Curso de Processo Penal: volume I. 3. ed. Rio de Janeiro: Lumes Juris, 2006.

LIMA, Renato Brasileiro de. Manual de processo penal. Niterói, RJ: Impetus, 2011.

LOPES JUNIOR, Aury. Direito Processual Penal. 12. ed. São Paulo: Saraiva, 2015.

LOPES JUNIOR, Aury. Direito Processual Penal: e sua conformidade constitucional. 7. ed. Rio de Janeiro: Lumen Juris, 2011.

LOPES JUNIOR, Aury. Fundamentos do Processo Penal: Introdução Crítica. 3. ed. São Paulo: Saraiva, 2017. Livro digital.

LOPES JUNIOR, Aury. Introdução crítica ao processo penal: fundamentos da instrumentalidade constitucional. 4. ed. Rio de Janeiro: Lumen Juris, 2006.

LOPES JUNIOR, Aury. Sistemas de Investigação preliminar no processo penal. 4. ed. Rio de Janeiro: Lumen Juris, 2006. 
LOPES JÚNIOR, Aury; RITTER, Ruiz. A Imprescindibilidade do Juiz das Garantias para uma Jurisdição Penal Imparcial: Reflexões a Partir da Teoria da Dissonância Cognitiva. In: Revista Magister de Direito Penal e Processual Penal. Porto Alegre: Magister, ago./set. 2016, v. 73. p. 12/24.

LOVATTI, Sheila Mayra Lustoza de Souza. Justiça penal negociada. Rio de Janeiro: Gramma, 2017.

LUZ, Denise; SILVEIRA, Leon Murelli. A Angústia de Decidir e o Juiz das Garantias no Projeto de Reforma do CPP: Uma importante Contribuição da Psicanálise para o Direito. In: Revista Magister de Direito Penal e Processual Penal. Porto Alegre: Magister, dez.jan. 2013, v. 51. p. $15 / 39$.

MACHADO, Leonardo Marcondes. Investigação Preliminar: por uma política de redução de dor. In: KHALED JR., Salah. H. (Coord.). Sistema penal e poder punitivo: estudos em homenagem ao prof. Aury Lopes Jr. Florianópolis: Empório do Direito, 2015. p. 333/343.

MACHADO, Leonardo Marcondes. O inquérito policial goza de contraditório (mitigado) e defesa (limitada). Disponível em $<$ https://www.conjur.com.br/2018-set-04/academia-policia-inqueritopolicial-goza-contraditorio-mitigado-defesa-limitada $>$. Acesso em 16 abr. 2019.

MARCÃO, Renato. Curso de processo penal. 4. ed. São Paulo: Saraiva Educação, 2018.

MAYA, André Machado. Imparcialidade e Processo Penal: da prevenção da competência ao juiz de garantias. Rio de Janeiro: Lumes Juris, 2011. 
MIRABETE, Julio Fabbrini. Código de processo penal interpretado: referências doutrinárias, indicações legais, resenha jurisprudencial. 9. ed. atual. São Paulo: Atlas, 2002.

MIRABETE, Julio Fabbrini. Processo Penal. 2. ed. São Paulo: Atlas, 1992.

MIRABETE, Julio Fabbrini. Processo Penal. 17. ed. São Paulo: Atlas, 2005.

MOREIRA, Rômulo de Andrade. O que temos a aprender com o sistema processual penal do Uruguai. Disponível em: $<$ https://www.conjur.com.br/2018-nov-28/romulo-moreira-precisamosaprender-processo-penal-uruguaio $>$. Acesso em 05 mai. 2019.

NASSIF, Aramis. Sistema processual penal brasileiro: a nostalgia autoritária. In: AZEVEDO E SOUZA, Bernardo de; SILVEIRA, Felipe Lazzari da (Orgs.). Democracia e(m) sistema penal. Porto Alegre: Canal Ciências Criminais, 2017. p. 74/89.

OLIVEIRA, Daniel Kessler de. Por que precisamos do juiz de garantias?. Disponível em <https://canalcienciascriminais.com.br/juiz-garantias/>. Acesso em 08 abr. 2019.

PACELLI, Eugênio; FISCHER, Douglas. Comentários ao Código de Processo Penal e sua Jurisprudência. 7. ed. São Paulo: Atlas, 2015.

PACELLI, Eugenio. Curso de Processo Penal. 21. ed. São Paulo: Atlas, 2017. 
PITOMBO, Antonio Sérgio Altiere de Moraes. Criar função do juiz de garantias é aprimorar proteção do indivíduo. Disponível em $<$ https://www.conjur.com.br/2017-mai-21/criar-funcao-juiz-garantiasaprimorar-protecao-individuo>. Acesso em 15 abr. 2019.

PRADO, Geraldo. Sistema acusatório: a conformidade constitucional das leis processuais penais. 4. ed. Rio de Janeiro: Lumen Juris, 2006.

RANGEL, Paulo. Direito Processual Penal. 18. ed. Rio de Janeiro: Lumen Juris, 2010.

RAVAZZANO, Fernanda. A experiência no Chile e a busca por um sistema acusatório no Brasil. Disponível em: $<$ https://canalcienciascriminais.com.br/a-experiencia-no-chile-e-a-buscapor-um-sistema-acusatorio-no-brasil/>. Acesso em 05 mai. 2019.

RIGHTS, Cour Européenne Des Droits De L'homme European Court Of Human. Case Of De Cubber V. Belgium (Application No. 9186/80) Judgment Strasbourg 26 October 1984. Disponível em $<$ http://cambodia.ohchr.org/sites/default/files/echrsource/de\%20Cubber\% 20v.\%20Belgium\%20[26\%20Oct\%201984]\%20[EN].pdf>. Acesso em 01 abr. 2019.

SARLET, Ingo Wolfgang; MARINONI, Luiz Guilherme; MITIDIERO, Daniel Francisco. Curso de direito constitucional. São Paulo: Revista dos Tribunais, 2012.

SCHREIBER, Simone. O juiz de garantias no projeto do código de processo penal. In: Boletim do IBCCRIM, São Paulo, ago. 2010, v. 18, n. 213, p. $02 / 03$. 
SENADO FEDERAL DO BRASIL. Disponível em $<$ https://www25.senado.leg.br/web/atividade/materias/-/materia/90645>. Acesso em 05 abr. 2019.

SENADO FEDERAL DO BRASIL. Anteprojeto de Reforma do Código de Processo Penal / Comissão de Juristas Responsável pela Elaboração de Anteprojeto de Reforma do Código de Processo Penal. - Brasília: Senado Federal, Subsecretaria de Edições Técnicas, 2009. Disponível em $<$ http://www2.senado.leg.br/bdsf/bitstream/handle/id/182956/000182956. pdf?sequence $=10>$. p. 05 . Acesso em 05 abr. 2019.

SENADO FEDERAL DO BRASIL. Parecer $n^{\circ}$, de 2009. Da comissão temporária de estudo da reforma do código de processo penal, sobre o Projeto de Lei do Senado $n^{0} 156$, de 2009, que reforma o Código de Processo Penal, e proposições anexadas. Disponível em $<$ https://www.migalhas.com.br/arquivo_artigo/art20091201-01.pdf>. Acesso em 08 abr. 2019. 